This document is the accepted version of a Submitted Work that was subsequently published in 'Environmental Science \& Technology', copyright $@$ American Chemical Society after peer review. To access the final edited and published work see: Chételat, J., Richardson, M.C., MacMillan, G.A., Amyot, M. and Poulain, A.J., 2018. Ratio of methylmercury to dissolved organic carbon in water explains methylmercury bioaccumulation across a latitudinal gradient from north-temperate to arctic lakes. Environmental science \& technology, 52(1), pp.79-88. DOI: https://doi.org/10.1021/acs.est.7b04180

\title{
1 The ratio of methylmercury to dissolved organic carbon in water explains methylmercury bioaccumulation across a latitudinal gradient from north-temperate to Arctic lakes
}

5 John Chételat ${ }^{\dagger *}$, Murray C. Richardson ${ }^{\ddagger}$, Gwyneth A. MacMillan ${ }^{\ddagger}$, Marc Amyot ${ }^{\ddagger}$, Alexandre J.

$7{ }^{\dagger}$ National Wildlife Research Centre, Environment and Climate Change Canada, Ottawa, ON,

8 Canada, K1A $0 \mathrm{H3}$

$9 \div$ Geography and Environmental Studies, Carleton University, Ottawa, ON, Canada, K1S 5B6

$10 ¥$ Centre d'études nordiques, Département de sciences biologiques, Université de Montréal,

11 Montréal, QC, Canada, H2V 2S9

$12 \S$ Biology, University of Ottawa, Ottawa, ON, Canada, K1N 6N5

\section{Corresponding author}

15 John Chételat

16 Phone: 613-991-9835; Fax: 613-998-0458; Email: john.chetelat@canada.ca

\section{Author contributions}

18 JC, MR, GM and MA designed the study. All authors contributed to data generation. Data were 19 analyzed by JC and MR. JC prepared the manuscript and all authors edited the manuscript.

20 Notes

21 The authors declare no competing financial interest. 
This document is the accepted version of a Submitted Work that was subsequently published in 'Environmental Science \& Technology', copyright @ American Chemical Society after peer review. To access the final edited and published work see: Chételat, J., Richardson, M.C., MacMillan, G.A., Amyot, M. and Poulain, A.J., 2018. Ratio of methylmercury to dissolved organic carbon in water explains methylmercury bioaccumulation across a latitudinal gradient from north-temperate to arctic lakes. Environmental science \& technology, 52(1), pp.79-88. DOI: https://doi.org/10.1021/acs.est.7b04180

\section{ABSTRACT}

23 We investigated monomethylmercury $(\mathrm{MMHg})$ bioaccumulation in lakes across a $30^{\circ}$ latitudinal

24 gradient in eastern Canada to test the hypothesis that climate-related environmental conditions

25 affect the sensitivity of Arctic lakes to atmospheric mercury contamination. Aquatic

26 invertebrates (chironomid larvae, zooplankton) provided indicators of MMHg bioaccumulation

27 near the base of benthic and planktonic food chains. In step with published data showing

28 latitudinal declines in atmospheric mercury deposition in Canada, we observed lower total

29 mercury concentrations in water and sediment of higher latitude lakes. Despite latitudinal

30 declines of inorganic mercury exposure, $\mathrm{MMHg}$ bioaccumulation in aquatic invertebrates did not

31 concomitantly decline. Arctic lakes with greater MMHg in aquatic invertebrates either had: (1)

32 higher water MMHg concentrations (reflecting ecosystem MMHg production) or (2) low water

33 concentrations of $\mathrm{MMHg}, \mathrm{DOC}$, chlorophyll and total nitrogen (reflecting lake sensitivity). The

34 MMHg:DOC ratio of surface water was a strong predictor of lake sensitivity to mercury

35 contamination. Bioaccumulation factors for biofilms and seston in Arctic lakes showed more

36 efficient uptake of MMHg in low DOC systems. Environmental conditions associated with low

37 biological production in Arctic lakes and their watersheds increased the sensitivity of lakes to

$38 \mathrm{MMHg}$. 
This document is the accepted version of a Submitted Work that was subsequently published in 'Environmental Science \& Technology', copyright @ American Chemical Society after peer review. To access the final edited and published work see: Chételat, J., Richardson, M.C., MacMillan, G.A., Amyot, M. and Poulain, A.J., 2018. Ratio of methylmercury to dissolved organic carbon in water explains methylmercury bioaccumulation across a latitudinal gradient from north-temperate to arctic lakes. Environmental science \& technology, 52(1), pp.79-88. DOI: https://doi.org/10.1021/acs.est.7b04180

\section{INTRODUCTION}

Lakes in the Canadian Arctic are exposed to inorganic mercury deposition through long-range atmospheric transport from emission sources in North America, Europe and East Asia. ${ }^{1}$

Atmospheric deposition rates of mercury decline with latitude in Canada, in part due to greater distance from emission sources and lower annual precipitation. ${ }^{2,3}$ Paradoxically, levels of mercury accumulating in northern fish species such as Arctic char (Salvelinus alpinus) do not concomitantly decline with latitude in the $\operatorname{Arctic}^{4,5}$, and elevated mercury (above $0.5 \mu \mathrm{g} / \mathrm{g}$ wet weight) has been observed in fish muscle from remote Arctic regions. ${ }^{6}$ Together, these observations suggest that Arctic lakes may be more sensitive to mercury loadings, and there is broad interest from governments and the scientific community to better elucidate the controls on mercury bioaccumulation in fish and wildlife that are traditional foods for northern peoples. ${ }^{7,8}$

Environmental conditions that are characteristic of northern latitude lakes could increase the sensitivity of those freshwater ecosystems to mercury bioaccumulation. Lake sensitivity, as defined by Munthe et al. ${ }^{9}$, is "the ability of an ecosystem to transform inorganic mercury load to methylmercury in biota". On a broad scale, temperature and precipitation decline with latitude in Canada, and those key climate drivers control biological production of lakes and their watersheds ${ }^{10}$. In this study, we hypothesized that Arctic lakes may be more sensitive to mercury bioaccumulation as a result of distinct features of those systems, specifically colder temperatures, lower aquatic primary production, and low terrestrial inputs of organic matter.

Monomethylmercury (MMHg) is the dominant bioaccumulative form of mercury, and climate-related variation in lake ecosystem characteristics could affect how it accumulates in 
This document is the accepted version of a Submitted Work that was subsequently published in 'Environmental Science \& Technology', copyright @ American Chemical Society after peer review. To access the final edited and published work see: Chételat, J., Richardson, M.C., MacMillan, G.A., Amyot, M. and Poulain, A.J., 2018. Ratio of methylmercury to dissolved organic carbon in water explains methylmercury bioaccumulation across a latitudinal gradient from north-temperate to arctic lakes. Environmental science \& technology, 52(1), pp.79-88. DOI: https://doi.org/10.1021/acs.est.7b04180

60 food chains. Organic matter strongly binds mercury and affects its availability for transfer across

61

bacterial or algal cell membranes, referred to as bioavailability. ${ }^{11}$ Low amounts of organic carbon in Arctic lakes may result in greater $\mathrm{MMHg}$ bioavailability to food chains through a greater portion of the inorganic mercury pool being bioavailable for microbial methylation ${ }^{12}$ or a greater portion of water $\mathrm{MMHg}$ being bioavailable for uptake by algae and bacteria. ${ }^{13-15}$ Separately, high algal biomass in water and on biofilms of temperate lakes will reduce mercury bioaccumulation in aquatic food chains because the cellular uptake of water MMHg is partitioned among more cells, a process referred to as biodilution. ${ }^{16-18}$ Biodilution may not occur in Arctic lakes where little algal biomass is present, resulting in greater MMHg concentration per unit biomass at the base of the food chain. Although these environmental controls on $\mathrm{MMHg}$ bioaccumulation have been demonstrated for temperate systems, much less is known about their applicability in Arctic environments.

This paper presents a study of MMHg bioaccumulation in lakes from four study regions spanning $30^{\circ}$ latitude in eastern Canada. We collected aquatic invertebrates from planktonic and benthic environments, specifically zooplankton and chironomid larvae (Insecta: Diptera), as indicators of $\mathrm{MMHg}$ accumulation near the base of the food chain. These invertebrate prey are effective indicators of $\mathrm{MMHg}$ accumulation in fish because fish are exposed to mercury primarily through their diet. ${ }^{19}$ Chironomids are a major food source for non-anadromous Arctic char in high-latitude lakes. ${ }^{20}$ We also examined bulk organic matter of seston and rock biofilms to estimate the efficiency of MMHg uptake from water. The main objectives of this research were to 1) characterize MMHg bioaccumulation in distinct ecosystem types (north temperate, sub-Arctic taiga, Arctic tundra, polar desert) found within the study's latitudinal gradient; and 2) 
This document is the accepted version of a Submitted Work that was subsequently published in 'Environmental Science \& Technology', copyright @ American Chemical Society after peer review. To access the final edited and published work see: Chételat, J., Richardson, M.C., MacMillan, G.A., Amyot, M. and Poulain, A.J., 2018. Ratio of methylmercury to dissolved organic carbon in water explains methylmercury bioaccumulation across a latitudinal gradient from north-temperate to arctic lakes. Environmental science \& technology, 52(1), pp.79-88. DOI: https://doi.org/10.1021/acs.est.7b04180

82 to investigate the importance of mercury exposure (water and sediment concentrations) and other

83 potential environmental controls on lake sensitivity to $\mathrm{MMHg}$ bioaccumulation. 
This document is the accepted version of a Submitted Work that was subsequently published in 'Environmental Science \& Technology', copyright @ American Chemical Society after peer review. To access the final edited and published work see: Chételat, J., Richardson, M.C., MacMillan, G.A., Amyot, M. and Poulain, A.J., 2018. Ratio of methylmercury to dissolved organic carbon in water explains methylmercury bioaccumulation across a latitudinal gradient from north-temperate to arctic lakes. Environmental science \& technology, 52(1), pp.79-88. DOI: https://doi.org/10.1021/acs.est.7b04180

\section{MATERIALS AND METHODS}

Study Sites. Field programs were conducted between 2011 and 2014 in four study areas that span a $30^{\circ}$ latitudinal gradient in eastern Canada (Figure 1). Base map imagery for Figure 1 was obtained from ESRI. ${ }^{21}$ The north-temperate study area, Gatineau Park $\left(46^{\circ} \mathrm{N}\right)$, is located in mixed deciduous and conifer forest, just north of Ottawa, Ontario. A sub-Arctic taiga landscape was investigated at Kuujjuaraapik-Whapmagoustui in northern Quebec $\left(55^{\circ} \mathrm{N}\right)$, located approximately $200 \mathrm{~km}$ south of the treeline boundary. Arctic tundra and polar desert landscapes were investigated in Nunavut at Iqaluit $\left(64^{\circ} \mathrm{N}\right)$ and Resolute Bay $\left(75^{\circ} \mathrm{N}\right)$, respectively. These study areas cover a large climate gradient, with declining mean daily air temperature $\left(21^{\circ}\right.$ to $5^{\circ} \mathrm{C}$ in July) and mean annual precipitation $(940 \mathrm{~mm}$ to $160 \mathrm{~mm}$ ) from the most southern to northern areas.

Field Sample Collection. A total of 35 lakes were investigated for MMHg bioaccumulation (see Supplementary Table S1 for locations and morphometry of lakes). Within each of the four study areas, 8 to 10 lakes were selected to encompass a range in lake surface area and depth, and thereby account for local physiographic influences on methylmercury exposure. The lakes were relatively small in size (range of surface area $=0.01-7.06 \mathrm{~km}^{2}$ ) and shallow (range of lake-mean depth $=0.5-13.7 \mathrm{~m})$. Lake morphometry was measured in a boat using GPS-linked sonar, and watershed areas were computed using available digital elevation models and standard terrain analysis methods. Water chemistry and biological sampling was conducted on one occasion in July at each lake in the three Arctic study areas. For Gatineau Park lakes, water chemistry was measured in spring and late summer over a two year period (3 or 4 sampling dates in 2011-12), while biological sampling was conducted on one occasion in the fall of 2011 or 2012. 
This document is the accepted version of a Submitted Work that was subsequently published in 'Environmental Science \& Technology', copyright @ American Chemical Society after peer review. To access the final edited and published work see: Chételat, J., Richardson, M.C., MacMillan, G.A., Amyot, M. and Poulain, A.J., 2018. Ratio of methylmercury to dissolved organic carbon in water explains methylmercury bioaccumulation across a latitudinal gradient from north-temperate to arctic lakes. Environmental science \& technology, 52(1), pp.79-88. DOI: https://doi.org/10.1021/acs.est.7b04180

At each lake, in situ water temperature, specific conductivity, $\mathrm{pH}$, and dissolved oxygen were measured with a YSI multi-parameter sonde (YSI Inc., Yellow Springs, Ohio, USA). Water was sampled in duplicate from each lake for mercury, dissolved organic carbon (DOC), total nitrogen (TN), total phosphorus (TP) (for Arctic lakes only) and chlorophyll $a$ (Chl). In the Arctic study areas, lakes were not thermally stratified or only weakly stratified, and water was collected as sub-surface grabs in Nalgene® PETG bottles for mercury analysis and in HDPE bottles for other water chemistry. In thermally stratified lakes at Gatineau Park, both surface water and deep hypolimnetic water ( $1 \mathrm{~m}$ above the sediment) were sampled for water chemistry by peristaltic pump and acid-washed teflon tubing or by acid-washed teflon Kemmerer bottle. Details of water sampling, including clean protocols for trace metals, are provided in the supplemental information.

Zooplankton and chironomid larvae were collected in each lake as representative invertebrates of pelagic and benthic environments, respectively. These freshwater invertebrates are ubiquitous, and within the Arctic, chironomids are the dominant benthic invertebrate in lakes. ${ }^{22}$ Two or three zooplankton samples per water body were collected with a large diameter $200 \mu \mathrm{m}$ mesh net by vertical or horizontal tows, depending on lake depth and ice conditions. Chironomid larvae were collected mainly from deeper, offshore sediments with an Ekman grab, although shoreline areas were occasionally sampled with a kicknet to increase yield. Typically, 3 replicate chironomid samples were collected per lake (range of 1-8). Prior to passing Ekman sediment grabs through a $500 \mu \mathrm{m}$ sieve, the top 1-2 cm of surface sediment was collected for chemical analysis. On the same day of collection, chironomid larvae were removed from sediment material with tweezers, washed in ultrapure water, and frozen. 
This document is the accepted version of a Submitted Work that was subsequently published in 'Environmental Science \& Technology', copyright @ American Chemical Society after peer review. To access the final edited and published work see: Chételat, J., Richardson, M.C., MacMillan, G.A., Amyot, M. and Poulain, A.J., 2018. Ratio of methylmercury to dissolved organic carbon in water explains methylmercury bioaccumulation across a latitudinal gradient from north-temperate to arctic lakes. Environmental science \& technology, 52(1), pp.79-88. DOI: https://doi.org/10.1021/acs.est.7b04180

Planktonic and benthic sources of basal organic matter were collected in the three Arctic study areas. Rock biofilms were sampled by scraping surface material from shoreline rocks with a nylon bristle brush. Three replicates (each composed of 5-10 rock scrapings) were collected per lake. Duplicate (or sometimes triplicate) seston samples were collected from nearshore water of lakes by passing $0.6-4 \mathrm{~L}$ of surface water $(<0.5 \mathrm{~m}$ depth) through a pre-weighed ashed GFF glass fibre filter $(0.7 \mu \mathrm{m}$ pore size $)$. Large particles were removed by pre-filtration at $53 \mu \mathrm{m}$ with an in-line system. Seston filtration was conducted either directly in the field with a peristaltic pump and acid-washed teflon line or in the lab on the same day of water collection using an acidwashed filtration tower.

Laboratory Analyses. Water was analyzed for mercury by cold vapor atomic fluorescence spectrometry (CVAFS) with a Tekran 2600 (total mercury [THg], $n=268$ ) or Tekran 2700 (MMHg, $n=266$ ) (Tekran® Instruments Corporation, Toronto, Canada). Water for MMHg analysis was distilled prior to derivatization by aqueous ethylation. Details of analytical methods for water mercury are in the supplementary information. Water Chl was measured by spectrophotometer after ethanol extraction, with the exception of Gatineau Park lakes where in situ Chl was measured with a YSI fluorescence probe, validated with Chl analyses by ethanol extraction of filtered seston for a subset of six lakes (Supplemental Figure S1). Water DOC was measured with a Pt-catalyzed Shimadzu TOC 5000 analyzer. Total nitrogen in water was determined as nitrate after potassium persulfate alkaline digestion, and total phosphorus was determined by spectrophotometer using the molybdenum blue method.

Freeze-dried and homogenized samples of chironomid larvae $(n=84)$ and biofilm organic matter $(n=70)$ from Arctic lakes were analyzed for MMHg by pretreatment with an alkaline 
This document is the accepted version of a Submitted Work that was subsequently published in 'Environmental Science \& Technology', copyright $@$ American Chemical Society after peer review. To access the final edited and published work see: Chételat, J., Richardson, M.C., MacMillan, G.A., Amyot, M. and Poulain, A.J., 2018. Ratio of methylmercury to dissolved organic carbon in water explains methylmercury bioaccumulation across a latitudinal gradient from north-temperate to arctic lakes. Environmental science \& technology, 52(1), pp.79-88. DOI: https://doi.org/10.1021/acs.est.7b04180

150 then acidic digestion, extraction in dichloromethane, isolation with sodium thiosulfate and

151 detection by capillary gas chromatography coupled with atomic fluorescence spectrometry at the

152 Laboratory for the Analysis of Natural and Commercial Environmental Toxins (LANCET,

153 University of Ottawa, Ottawa, Canada). Concentrations of MMHg in chironomid larvae from

154 Gatineau Park $(n=38)$ and all seston $(n=48)$ and zooplankton $(n=55)$ samples were

155 determined by acid digestion, derivatization by aqueous ethylation, and detection by CVAFS at

156 the Laboratoire de biogéochimie environnementale (Université de Montréal, Montreal, Canada).

157 Method details are provided in the supplementary information.

The THg concentration of freeze-dried and homogenized surface sediment $(n=151)$ was

measured with a Direct Mercury Analyzer (Milestone Inc, Shelton, Connecticut, USA). The ignition (LOI) was measured on rock biofilms and a subset of sediment samples by combustion in a muffle oven at $550^{\circ} \mathrm{C}$ for $4 \mathrm{~h}$. Because some sediment samples from Gatineau Park lakes

164 were lost before LOI determinations could be completed, $\% \mathrm{~N}$ was used as a surrogate measure of organic matter in sediment. For a subset of sediment samples, percent organic matter content by LOI was strongly correlated with sediment $\% \mathrm{~N}$ across study regions (Pearson $\mathrm{r}=0.91, \mathrm{p}<0.001$, $167 \mathrm{n}=102)$. certified reference materials, duplicate repeatability, method detection limits) are provided in the supplementary information. All chemical concentrations in biological samples and sediment are

171 presented on a dry weight basis. The MMHg concentration in rock biofilm was normalized for 
This document is the accepted version of a Submitted Work that was subsequently published in 'Environmental Science \& Technology', copyright @ American Chemical Society after peer review. To access the final edited and published work see: Chételat, J., Richardson, M.C., MacMillan, G.A., Amyot, M. and Poulain, A.J., 2018. Ratio of methylmercury to dissolved organic carbon in water explains methylmercury bioaccumulation across a latitudinal gradient from north-temperate to arctic lakes. Environmental science \& technology, 52(1), pp.79-88. DOI: https://doi.org/10.1021/acs.est.7b04180

172 percent organic matter content (ng/g OM) by loss on ignition measurements due to variable

173 amounts inorganic material. Seston MMHg concentration was normalized for the mass of

174 particulate matter on the sample filter (ng MMHg/g of seston). Half the detection limit was used

175 for MMHg results below detection for 16 seston samples $(<0.4 \mathrm{ng} / \mathrm{g})$ and three unfiltered water

176 samples $(<0.01 \mathrm{ng} / \mathrm{L})$.

Data Analysis. Mercury concentrations in water, sediment and biota were compared with

Kuujjuaraapik). ${ }^{2}$ 
This document is the accepted version of a Submitted Work that was subsequently published in 'Environmental Science \& Technology', copyright @ American Chemical Society after peer review. To access the final edited and published work see: Chételat, J., Richardson, M.C., MacMillan, G.A., Amyot, M. and Poulain, A.J., 2018. Ratio of methylmercury to dissolved organic carbon in water explains methylmercury bioaccumulation across a latitudinal gradient from north-temperate to arctic lakes. Environmental science \& technology, 52(1), pp.79-88. DOI: https://doi.org/10.1021/acs.est.7b04180

194 WRT was estimated using lake volume, lake and catchment area, and the mean annual runoff 195 (mm/year) specific to each study region (see supplementary information for details). Filtered 196 water $\mathrm{MMHg}$ concentrations were not available for all lakes but filtered and unfiltered $\mathrm{MMHg}$ 197 concentrations were highly correlated (Pearson $r=0.98, p<0.001$ ) for a subset of 25 lakes.

198 PCA variables were log-transformed, centered and standardized. In the case of missing values 199 for sediment THg (1 lake), water Chl (2 lakes), and zooplankton MMHg (1 lake), the mean value 200 of all lakes in that study area was used for the PCA.

201 A non-parametric approach, Spearman correlation analysis, was used to assess the importance 202 of water quality variables on $\mathrm{MMHg}$ bioaccumulation in invertebrates due to non-linearity of 203 some relationships. Partial Spearman correlation coefficients were calculated in R using the 204 PPCOR library to control for the effect of water MMHg concentration.

Bioaccumulation factors (BAFs) were calculated to estimate the efficiency of uptake of water $206 \mathrm{MMHg}$ in planktonic and benthic organic matter from Arctic lakes. No data were available for 207 basal organic matter components from the Gatineau Park study area. The BAFs were determined 208 as the logarithm of seston or biofilm MMHg concentration (ng/kg) divided by dissolved $\mathrm{MMHg}$ 209 concentration in surface water $(\mathrm{ng} / \mathrm{kg})$, following conversion of the water concentration from a 210 volume basis (ng/L) to a weight basis (ng/kg). Correlation analysis was conducted between 211 BAFs in basal organic matter and water DOC, TN, and Chl concentrations to test the hypothesis 212 that water quality conditions affected the efficiency of MMHg uptake at the base of the food 213 chain. 
This document is the accepted version of a Submitted Work that was subsequently published in 'Environmental Science \& Technology', copyright @ American Chemical Society after peer review. To access the final edited and published work see: Chételat,

J., Richardson, M.C., MacMillan, G.A., Amyot, M. and Poulain, A.J., 2018. Ratio of methylmercury to dissolved organic carbon in water explains methylmercury bioaccumulation across a latitudinal gradient from north-temperate to arctic lakes. Environmental science \& technology, 52(1), pp.79-88. DOI: https://doi.org/10.1021/acs.est.7b04180

\section{RESULTS AND DISCUSSION}

215 Latitudinal Trends. Model estimates of atmospheric mercury deposition (from Muir et al. ${ }^{2}$ ) indicate that recent annual fluxes decline approximately five-fold between the most southern study area, Gatineau Park $\left(46^{\circ} \mathrm{N}\right)$, and the most northern area, Resolute Bay $\left(75^{\circ} \mathrm{N}\right)$ (Figure 1). distance from major anthropogenic emission sources. ${ }^{3}$ In step with the deposition pattern, we observed significant latitudinal declines of THg concentration in both water (Spearman rho = $0.43, p=0.011, n=35)$ and sediment (Spearman $r h o=-0.86, p<0.001, n=34)$ (Figure 1). Surface sediment $\mathrm{THg}$ was correlated with $\% \mathrm{~N}$ (a surrogate of organic matter content) and lake depth (Supplemental Figure S2). After controlling for those two factors, a latitudinal decline in sediment THg concentration was still evident (Supplemental Figure S3). Water MMHg concentration also declined with latitude (Spearman rho $=-0.73, p<0.001, n=35$; Figure 1), and low levels $(<0.05 \mathrm{ng} \mathrm{MMHg/L)}$ were found in tundra and polar desert lakes. For northtemperate lakes in Gatineau Park, water THg and MMHg were affected by thermal stratification, with low concentrations found in the epilimnion (surface water) and, on average, 2-fold and 12fold higher values of $\mathrm{THg}$ and $\mathrm{MMHg}$, respectively, in the hypolimnion (1 $\mathrm{m}$ above sediment, depth range of 7-21 m among lakes; Supplemental Figure S4). Thermal stratification and higher water column sedimentation rates may explain the somewhat lower concentrations of water $\mathrm{THg}$

232 in the Gatineau Park study region (Figure 1). When only considering surface waters, $\mathrm{MMHg}$ 233 concentrations were highest at sub-Arctic Kuujjuaraapik (Supplemental Table S3).

Despite the latitudinal decline in inorganic mercury exposure in our study lakes, 
This document is the accepted version of a Submitted Work that was subsequently published in 'Environmental Science \& Technology', copyright @ American Chemical Society after peer review. To access the final edited and published work see: Chételat, J., Richardson, M.C., MacMillan, G.A., Amyot, M. and Poulain, A.J., 2018. Ratio of methylmercury to dissolved organic carbon in water explains methylmercury bioaccumulation across a latitudinal gradient from north-temperate to arctic lakes. Environmental science \& technology, 52(1), pp.79-88. DOI: https://doi.org/10.1021/acs.est.7b04180

2). The highest concentrations of $\mathrm{MMHg}$ in both zooplankton and chironomids were observed in sub-Arctic and polar desert lakes even though the latter study area was estimated to receive the lowest atmospheric mercury deposition and had the lowest $\mathrm{THg}$ in water and sediment. Mean MMHg concentrations of chironomids (69 ng/g) and zooplankton (65 ng/g) from polar desert lakes were higher than mean or median MMHg levels $(<50 \mathrm{ng} / \mathrm{g})$ in zooplankton and primary consumer invertebrates reported in the literature for north-temperate lakes. ${ }^{23,24}$ These observations contrast with earlier reports of strong positive correlations between wet atmospheric deposition of inorganic mercury and $\mathrm{MMHg}$ bioaccumulation in aquatic invertebrates ${ }^{25}$ and fish $^{26}$ from a broad-scale sampling of water bodies in the United States. We do not view these results as contradicting the importance of atmospheric deposition, given the well-established experimental relationship between inorganic mercury loading and methylmercury bioaccumulation in lakes. ${ }^{27,} 28$ Rather the findings suggest there are unique environmental characteristics in high latitude lakes that enhance MMHg bioaccumulation in spite of low inorganic mercury loads.

\section{Environmental Gradients among the Study Lakes. The study lakes varied in size as} indicated in the PCA by the clustering of lake area, mean depth, WRT, and LV:CA (Figure 3). A range of lake sizes were sampled within each study area, although sites from Kuujjuaraapik and Resolute Bay tended to be smaller. There were lower values of water Chl, surface water temperature, water DOC, and sediment $\mathrm{THg}$ (and to a lesser extent water TN and bottom temperature) in the tundra and polar desert lakes, and higher values in temperate and sub-Arctic lakes (Figure 3, Table S3). These variables reflect a latitudinal decline in the presence of organic matter (DOC range: 0.8-7.6 mg/L; Chl range: 0.1-3.0 $\mu \mathrm{g} / \mathrm{L}$ ) and temperature conditions (range 
This document is the accepted version of a Submitted Work that was subsequently published in 'Environmental Science \& Technology', copyright @ American Chemical Society after peer review. To access the final edited and published work see: Chételat, J., Richardson, M.C., MacMillan, G.A., Amyot, M. and Poulain, A.J., 2018. Ratio of methylmercury to dissolved organic carbon in water explains methylmercury bioaccumulation across a latitudinal gradient from north-temperate to arctic lakes. Environmental science \& technology, 52(1), pp.79-88. DOI: https://doi.org/10.1021/acs.est.7b04180

258

for surface water: $2-22^{\circ} \mathrm{C}$ ) within the dataset. Water TP data were only available for Arctic lakes but concentrations were consistently low (median $=4.7 \mu \mathrm{g} / \mathrm{L}$, range $=1.2-9.6 \mu \mathrm{g} / \mathrm{L}, n=25$ lakes, Table S3) and did not differ significantly among Arctic study regions (one way ANOVA, $p=0.15, n=24$ lakes). Water $\mathrm{pH}$ and specific conductivity (correlated with the CA:LA ratio) also varied among lakes (Figure 3), although the waters had circumneutral or alkaline $\mathrm{pH}$ (among-lake mean $\mathrm{pH}=7.5$, range $=6.6-8.3$ ).

Water Quality Controls on Invertebrate MMHg. We tested the influence of water quality variables on $\mathrm{MMHg}$ concentrations in aquatic invertebrates across the latitudinal gradient. Surface water MMHg concentration best explained MMHg levels in both groups of aquatic invertebrates (Table 1). These correlations reflect the importance of water MMHg exposure for food chain bioaccumulation. ${ }^{27,28}$ After controlling for the effect of surface water MMHg using partial correlation analysis, three water quality variables—-DOC, TN, and $\mathrm{Chl} —$ showed significant negative correlations with invertebrate $\mathrm{MMHg}$ concentrations (Table 1). Thus, greater bioaccumulation was also associated with Arctic lakes that had lower water concentrations of DOC, Chl and TN. Water temperature, specific conductivity and $\mathrm{pH}$ were not significant explanatory variables of invertebrate $\mathrm{MMHg}$ concentrations (Table 1). We generated multiple regression models using surface water $\mathrm{MMHg}$ and each of the three water quality variables (DOC, TN, Chl) to identify the strongest explanatory variables for invertebrate $\mathrm{MMHg}$ concentrations (Supplemental Table S3). Surface water MMHg and DOC together best explained MMHg in both chironomids (model $\left.r_{a d j}^{2}=0.55, p<0.001, n=35\right)$ and zooplankton (model $r^{2}{ }_{a d j}$ $=0.45, p<0.001, n=34)$. For zooplankton, the models including $\mathrm{TN}$ or $\mathrm{Chl}$ had similar though slightly lower explanatory power ( $r^{2}$ adj of 0.41 and 0.39 , respectively). This analysis indicates 
This document is the accepted version of a Submitted Work that was subsequently published in 'Environmental Science \& Technology', copyright @ American Chemical Society after peer review. To access the final edited and published work see: Chételat, J., Richardson, M.C., MacMillan, G.A., Amyot, M. and Poulain, A.J., 2018. Ratio of methylmercury to dissolved organic carbon in water explains methylmercury bioaccumulation across a latitudinal gradient from north-temperate to arctic lakes. Environmental science \& technology, 52(1), pp.79-88. DOI: https://doi.org/10.1021/acs.est.7b04180

280

281

282

283

284

285

286

287

288

289

290

291

292

293

294

that low DOC and oligotrophic conditions of Arctic lakes enhanced MMHg bioaccumulation near the base of benthic and planktonic food chains.

An important implication of these findings is that $\mathrm{MMHg}$ bioaccumulation in northern Canadian lakes reflects a balance between $\mathrm{MMHg}$ supply to the water column and lake sensitivity to uptake in the food chain. This balance can be empirically represented by the ratio of MMHg to DOC concentrations in surface waters (Figure 4). Across our latitudinal gradient, lakes with greater levels of $\mathrm{MMHg}$ in aquatic invertebrates either had high surface water $\mathrm{MMHg}$ concentrations (greater ecosystem production of $\mathrm{MMHg}$ ) or lower $\mathrm{MMHg}$ in water but also very low water DOC (greater lake sensitivity to $\mathrm{MMHg}$ exposure). We propose that this water quality variable (the MMHg:DOC ratio) may be useful to identify Arctic lakes that are more sensitive to $\mathrm{MMHg}$ bioaccumulation, and further research is warranted to investigate its broader applicability. For example, we tested the MMHg:DOC ratio on a previously published dataset of chironomid larvae from 20 lakes in the Canadian high Arctic ${ }^{29}$ and found a strong positive correlation between chironomid $\mathrm{MMHg}$ concentration and the $\mathrm{MMHg}$ :DOC ratio in surface waters $\left(r^{2} a d j=0.52, p<0.001, n=20\right.$; Supplemental Figure S5).

\section{Bioaccumulation Factors for MMHg in Benthic and Planktonic Organic Matter.}

Concentrations of MMHg in basal organic matter varied among our Arctic study lakes from

$2-12 \mathrm{ng} / \mathrm{gOM}$ in rock biofilms (mean \pm 1 standard deviation $=5 \pm 2 \mathrm{ng} / \mathrm{gOM}, n=24$ lakes) and $<0.4-30 \mathrm{ng} / \mathrm{g}$ in seston (mean \pm 1 standard deviation $=4 \pm 7 \mathrm{ng} / \mathrm{g}, n=22$ lakes). The Arctic

biofilm MMHg concentrations were lower than values reported for boreal lakes in eastern

Canada $\left(47-50^{\circ} \mathrm{N}\right)$, which averaged $11 \mathrm{ng} / \mathrm{g}(\mathrm{range}=3-55 \mathrm{ng} / \mathrm{g}) .{ }^{30} \mathrm{Similarly}$, our estimates of $\mathrm{MMHg}$ in Arctic seston were lower than values reported for sites in the Great Lakes Region 
This document is the accepted version of a Submitted Work that was subsequently published in 'Environmental Science \& Technology', copyright @ American Chemical Society after peer review. To access the final edited and published work see: Chételat, J., Richardson, M.C., MacMillan, G.A., Amyot, M. and Poulain, A.J., 2018. Ratio of methylmercury to dissolved organic carbon in water explains methylmercury bioaccumulation across a latitudinal gradient from north-temperate to arctic lakes. Environmental science \& technology, 52(1), pp.79-88. DOI: https://doi.org/10.1021/acs.est.7b04180

302 (which often exceeded > $10 \mathrm{ng} / \mathrm{g}$ ). ${ }^{31}$ There was no difference in mean biofilm $\mathrm{MMHg}$

303

304

305

306

307

308

309

310

311

312

313

314

315

316

317

318

concentrations among our three Arctic study areas (one-way ANOVA, $p=0.51, n=25$ lakes),

while significantly higher seston $\mathrm{MMHg}$ concentrations were measured in polar desert lakes

compared to tundra and sub-Arctic lakes (one-way ANOVA, $p<0.001, n=22$ lakes)

(Supplemental Figure S6).

BAFs between dissolved water MMHg and basal organic matter sources suggested there was greater accumulation of MMHg in higher latitude lakes at Iqaluit and Resolute Bay. BAFs for MMHg in both seston and rock biofilms were negatively correlated with water quality variables, mainly DOC (Figure 5), but also Chl $(\mathrm{p}<0.002)$ and TN $(p<0.001$ for biofilms; $\mathrm{p}>0.05$ for seston). Watras et al. ${ }^{13}$ similarly measured higher partitioning of $\mathrm{MMHg}$ between water and seston in Wisconsin lakes that had lower DOC concentrations. Our observations for Arctic lakes indicate a more efficient uptake of $\mathrm{MMHg}$ from water to benthic and plankton organic matter in ultra-oligotrophic, low DOC systems, which could explain the greater lake sensitivity to $\mathrm{MMHg}$ bioaccumulation observed for aquatic invertebrates (Figure 2, 4).

Estimates of MMHg in basal organic matter should be interpreted with caution because these bulk samples contained a mix of organic matter types—namely algae, detritus, bacteria and protozoa — and their complex composition likely varied among lakes. Future research on Arctic seston quality and potential influences on $\mathrm{MMHg}$ accumulation seems warranted. Similarly, zooplankton and chironomids are selective feeders, and the MMHg estimates may not accurately reflect dietary exposure for those aquatic invertebrates. Additional measurements of seston $\mathrm{MMHg}$ in different size fractions and over the growing season may better characterize trophic transfer of MMHg to Arctic zooplankton. Few published measurements of MMHg in lake seston 
This document is the accepted version of a Submitted Work that was subsequently published in 'Environmental Science \& Technology', copyright @ American Chemical Society after peer review. To access the final edited and published work see: Chételat, J., Richardson, M.C., MacMillan, G.A., Amyot, M. and Poulain, A.J., 2018. Ratio of methylmercury to dissolved organic carbon in water explains methylmercury bioaccumulation across a latitudinal gradient from north-temperate to arctic lakes. Environmental science \& technology, 52(1), pp.79-88. DOI: https://doi.org/10.1021/acs.est.7b04180

324 exist, and our estimates are among the first for Arctic fresh waters. There were technical

325 challenges in obtaining sufficient sample from some oligotrophic lakes, and seston $\mathrm{MMHg}$

326 concentrations were below analytical detection at several sites. Despite these limitations, we

327 found consistent patterns for two independent measurements on organic matter (biofilms,

328 seston), suggesting greater uptake of $\mathrm{MMHg}$ occurred at the base of benthic and planktonic food 329 chains in unproductive, low-DOC lakes in the Canadian Arctic.

scale, climate controls the biological production of lakes and their watersheds in northern resulted from greater bioavailability of dissolved MMHg in low DOC waters ${ }^{13-15}$ or a lack of biodilution in waters with little algal biomass, a process that reduces $\mathrm{MMHg}$ exposure to invertebrate grazers in more productive temperate systems. ${ }^{16,32}$ Concentrations of DOC in some polar desert lakes are so low as to be insufficient to catalyze photochemical breakdown of $\mathrm{MMHg}^{33}$, and lower turnover of water $\mathrm{MMHg}$ may have also played a role in enhancing $\mathrm{MMHg}$ bioaccumulation, if this loss process was insignificant. Likewise, phytoplankton production in polar desert lakes is extremely low due to poor nutrient availability and cold temperatures. ${ }^{34}$

341 Given the strong collinearity between water DOC and algal biomass (estimated by Chl) among 342 the study lakes, our models could not distinguish the contributions of each of those 343 environmental drivers. Further, lakes were sampled on one occasion, and seasonal variation in 344 water quality (particularly algal biomass) and MMHg bioaccumulation was not constrained. 
This document is the accepted version of a Submitted Work that was subsequently published in 'Environmental Science \& Technology', copyright @ American Chemical Society after peer review. To access the final edited and published work see: Chételat, J., Richardson, M.C., MacMillan, G.A., Amyot, M. and Poulain, A.J., 2018. Ratio of methylmercury to dissolved organic carbon in water explains methylmercury bioaccumulation across a latitudinal gradient from north-temperate to arctic lakes. Environmental science \& technology, 52(1), pp.79-88. DOI: https://doi.org/10.1021/acs.est.7b04180

346 DOC and primary productivity for $\mathrm{MMHg}$ bioaccumulation since climate warming during the $21^{\text {st }}$ century will stimulate both watershed loadings of DOC and algal growth in Arctic lakes. ${ }^{35}$ been reported. In those regions, the positive association is related to mercury transport from watersheds to lakes that is facilitated by downstream flow of mercury-bound $\mathrm{DOC}^{11}$, resulting in more aqueous inorganic and methyl mercury in higher DOC lakes. ${ }^{36,39}$ In Arctic lakes with snow-dominated hydrology, mercury transport to lakes occurs largely via snowmelt runoff in spring when soils are still frozen. ${ }^{40}$ DOC also affects mercury cycling through complexation processes that mediate cellular uptake of inorganic mercury or MMHg by bacteria ${ }^{12}$ and algae ${ }^{14}$.

357 The source of DOC (e.g., humic acids from terrestrial soils, in situ algal production) can also affect mercury bioavailability. ${ }^{41}$ Our measurements of water DOC did not take into account the complexity of organic matter sources. The diversity of watershed vegetation, soil and permafrost conditions as well as variable contributions of autochthonous primary production likely resulted in DOC of different chemical composition among study lakes across the latitudinal gradient.

362 Future research is recommended to examine the role of DOC source and composition in 363 enhanced mercury bioaccumulation in the high Arctic.

The species composition of aquatic invertebrates differed among study areas, which may have influenced the observed MMHg bioaccumulation patterns. Zooplankton diversity declines with latitude in Canada, ${ }^{42}$ and large-sized Daphnia (water flea) or anostracans (fairy shrimp) can be a significant component of Arctic zooplankton, particularly in small fishless lakes. Those taxa 
This document is the accepted version of a Submitted Work that was subsequently published in 'Environmental Science \& Technology', copyright @ American Chemical Society after peer review. To access the final edited and published work see: Chételat, J., Richardson, M.C., MacMillan, G.A., Amyot, M. and Poulain, A.J., 2018. Ratio of methylmercury to dissolved organic carbon in water explains methylmercury bioaccumulation across a latitudinal gradient from north-temperate to arctic lakes. Environmental science \& technology, 52(1), pp.79-88. DOI: https://doi.org/10.1021/acs.est.7b04180

368 bioaccumulate more $\mathrm{MMHg}$ than copepods ${ }^{43}$, and their presence may have contributed to the trend of higher MMHg concentrations at more northern latitudes (Figure 2). In a temperate lake, Todorova et al. ${ }^{44}$ similarly observed that shifts in species composition towards larger Daphnia 371 species increased the MMHg concentrations of bulk zooplankton. Little information is available 372 on taxonomic differences in $\mathrm{MMHg}$ bioaccumulation among chironomids although most in our 373 samples were from one grouping (subfamily Chironominae).

Our Arctic study lakes were located in coastal areas, which receive enhanced deposition of 375 inorganic mercury from spring atmospheric mercury depletion events (AMDEs) ${ }^{45,46}$ as well as $376 \mathrm{MMHg}$ deposition following atmospheric breakdown of volatile dimethylmercury of marine 377 origin. ${ }^{4-49}$ Considerable polar research has demonstrated that much of the inorganic mercury 378 deposited onto snow during AMDEs quickly revolatilizes back to the atmosphere within a few 379 days. ${ }^{50,51}$ We observed low $\mathrm{THg}$ concentrations in water and sediment from the Arctic lakes, 380 including declining trends with latitude, suggesting that AMDEs were not a major source of 381 inorganic mercury. Water MMHg concentrations in polar desert lakes at Resolute were low but 382 slightly higher than in tundra lakes at Iqaluit relative to the amount of water THg present (mean $\% \mathrm{MMHg}$ of $6 \%$ at Resolute vs $2 \%$ at Iqaluit). Given the slow rates of sediment mercury methylation in polar desert lakes ${ }^{52}$ and their low sediment $\mathrm{MMHg}_{\text {concentrations }}{ }^{29}$, a marine

385 source of MMHg (via breakdown of evaded dimethlymercury) may have contributed to 386 bioaccumulation in those food chains. Microbially-mediated production of MMHg also occurs in 387 in sediments of Arctic lakes and is controlled by redox conditions, sulfate and DOC 388 concentrations, and temperature. ${ }^{53}$ Irrespective of unique mercury biogeochemical processes that 
This document is the accepted version of a Submitted Work that was subsequently published in 'Environmental Science \& Technology', copyright @ American Chemical Society after peer review. To access the final edited and published work see: Chételat, J., Richardson, M.C., MacMillan, G.A., Amyot, M. and Poulain, A.J., 2018. Ratio of methylmercury to dissolved organic carbon in water explains methylmercury bioaccumulation across a latitudinal gradient from north-temperate to arctic lakes. Environmental science \& technology, 52(1), pp.79-88. DOI: https://doi.org/10.1021/acs.est.7b04180

occur in Arctic coastal areas, water DOC, TN, and Chl were important environmental variables explaining $\mathrm{MMHg}$ bioaccumulation.

\section{Implications for the Fate of Mercury Deposition in Arctic Lakes. Our research}

demonstrates that Arctic lakes with very low DOC, TN and algal biomass are more sensitive to mercury contamination despite low levels of inorganic mercury loading. The Arctic Archipelago, which covers 1.4 million $\mathrm{km}^{2}$ of northern Canada, is largely polar desert, and there are numerous unproductive lakes that are potentially sensitive. The MMHg:DOC ratio in surface waters may be useful as a preliminary indicator of enhanced $\mathrm{MMHg}$ bioaccumulation across this vast territory. Long-term climate warming in the Arctic will likely alter MMHg bioaccumulation in lakes, and our findings indicate that reductions in food chain accumulation may occur in polar desert lakes if there is increased production and transport of DOC or greater algal growth. Indeed, long-term monitoring of landlocked Arctic char from polar desert lakes at Resolute Bay indicates that their mercury concentrations have been declining over the last decade. ${ }^{54}$ However, mercury levels in fish have been recently increasing in other regions of the Canadian Arctic ${ }^{55,56}$, potentially reflecting an increase in global mercury emissions, or climate-related changes in watershed mercury transport (including from permafrost melt) and MMHg production. ${ }^{57}$ Further effort is needed to synthesize the various contributions of changing environmental processes on MMHg accumulation in Arctic lake food chains. Over the last century, the anthropogenic mercury flux to Canadian Arctic lakes has increased by an estimated 3.5 fold. ${ }^{2}$ Our findings emphasize the importance of continuing global efforts under the UNE Minamata Convention on Mercury to reduce anthropogenic mercury emissions because of their significant impact on sensitive ecosystems even at lower levels of atmospheric deposition. 
This document is the accepted version of a Submitted Work that was subsequently published in 'Environmental Science \& Technology', copyright $@$ American Chemical Society after peer review. To access the final edited and published work see: Chételat, J., Richardson, M.C., MacMillan, G.A., Amyot, M. and Poulain, A.J., 2018. Ratio of methylmercury to dissolved organic carbon in water explains methylmercury bioaccumulation across a latitudinal gradient from north-temperate to arctic lakes. Environmental science \& technology, 52(1), pp.79-88. DOI: https://doi.org/10.1021/acs.est.7b04180

\section{1 \\ ASSOCIATED CONTENT}

\section{Supporting Information}

413 Locations and morphometry of the study lakes; details of water sampling methods; details of

414 methods and QA/QC for mercury analyses; latitudinal trends of sediment $\mathrm{THg}$; comparison of

415 mercury in surface and bottom waters of Gatineau Park lakes; multiple regression models for

$416 \mathrm{MMHg}$ in aquatic invertebrates; chironomid MMHg in relation to water MMHg:DOC ratio for a

417 published dataset; $\mathrm{MMHg}$ in rock biofilms and seston from Arctic lakes.

\section{AUTHOR INFORMATION}

419 Corresponding Author

$420 \quad *$ Email: john.chetelat@ canada.ca

$421 \quad$ Notes

422 The authors declare no competing financial interests.

423 ACKNOWLEDGEMENTS

424 This work was conducted with financial support from the Northern Contaminants Program 425 (project M-16; Indigenous and Northern Affairs Canada), the Polar Continental Shelf Project

426 (projects 20113 \& 21514; Natural Resources Canada), NSERC Discovery grants to MA

427 (217099-2012) and MR (402226-2012), the National Capital Commission (2012 to 2013), and

428 scholarships to GM (NSERC, FRQ-NT, Richard J. Schmeelk Canada, and Northern Scientific

429 Training Program). The authors are grateful to Jamal Shirley and Rick Armstrong (Nunavut

430 Research Institute), Alec Tuckatuck (Sakkaq Landholding Corp.) and Claude Tremblay (Centre

431 d'études nordiques) for Arctic logistical support. We thank Jimmy Paul Angatookalook, Gayle

432 Kabloona, Steven Lonsdale, Joeffrey Okalik, Pilipooise Iqaluk, and Shen Wang for assistance in 
This document is the accepted version of a Submitted Work that was subsequently published in 'Environmental Science \& Technology', copyright @ American Chemical Society after peer review. To access the final edited and published work see: Chételat, J., Richardson, M.C., MacMillan, G.A., Amyot, M. and Poulain, A.J., 2018. Ratio of methylmercury to dissolved organic carbon in water explains methylmercury bioaccumulation across a latitudinal gradient from north-temperate to arctic lakes. Environmental science \& technology, 52(1), pp.79-88. DOI: https://doi.org/10.1021/acs.est.7b04180

433 the field, and Dominic Belanger, Emmanuel Yumvihoze, Hardeep Gill, and Michelle Zanuttig

434 for assistance in the laboratory. 
This document is the accepted version of a Submitted Work that was subsequently published in 'Environmental Science \& Technology', copyright @ American Chemical Society after peer review. To access the final edited and published work see: Chételat, J., Richardson, M.C., MacMillan, G.A., Amyot, M. and Poulain, A.J., 2018. Ratio of methylmercury to dissolved organic carbon in water explains methylmercury bioaccumulation across a latitudinal gradient from north-temperate to arctic lakes. Environmental science \& technology, 52(1), pp.79-88. DOI: https://doi.org/10.1021/acs.est.7b04180

Table 1. Spearman rho coefficients for correlations between surface water chemistry and

MMHg concentrations in chironomids $(n=35)$ and zooplankton $(n=34)$. Partial Spearman

rho coefficients were also determined after controlling for the effect of water MMHg.

\begin{tabular}{lcccccc}
\hline & \multicolumn{2}{c}{ Spearman rho } & & \multicolumn{2}{c}{ Partial Spearman rho } \\
\cline { 2 - 3 } \cline { 5 - 6 } Explanatory Variable & $\begin{array}{c}\text { Chironomid } \\
\text { MMHg }\end{array}$ & $\begin{array}{c}\text { Zooplankton } \\
\text { MMHg }\end{array}$ & & $\begin{array}{c}\text { Chironomid } \\
\text { MMHg }\end{array}$ & $\begin{array}{c}\text { Zooplankton } \\
\text { MMHg }\end{array}$ \\
\hline Chl $(\mu \mathrm{g} / \mathrm{L})$ & $-0.34^{*}$ & 0.07 & & $-0.68^{* * *}$ & -0.29 \\
$\mathrm{DOC}(\mathrm{mg} / \mathrm{L})$ & $-0.37^{*}$ & 0.03 & & $-0.77^{* * *}$ & $-0.40^{*}$ \\
$\mathrm{pH}$ & 0.18 & -0.14 & & 0.19 & -0.15 \\
Conductivity $(\mu \mathrm{S} / \mathrm{cm})$ & 0.31 & -0.05 & & 0.26 & -0.17 \\
Temperature ${ }^{\alpha}\left({ }^{\circ} \mathrm{C}\right)$ & 0.12 & -0.16 & & -0.22 & -0.28 \\
TN $(\mu \mathrm{g} / \mathrm{L})$ & 0.01 & 0.11 & & $-0.51 * * *$ & $-0.56^{* * *}$ \\
Water MMHg $(\mathrm{ng} / \mathrm{L})$ & $0.45^{* *}$ & $0.61^{* * *}$ & & --- & --- \\
\hline
\end{tabular}

$439{ }^{\alpha}$ Surface water temperature for zooplankton, bottom water temperature for chironomids 
This document is the accepted version of a Submitted Work that was subsequently published in 'Environmental Science \& Technology', copyright $@$ American Chemical Society after peer review. To access the final edited and published work see: Chételat, J., Richardson, M.C., MacMillan, G.A., Amyot, M. and Poulain, A.J., 2018. Ratio of methylmercury to dissolved organic carbon in water explains methylmercury bioaccumulation across a latitudinal gradient from north-temperate to arctic lakes. Environmental science \& technology, 52(1), pp.79-88. DOI: https://doi.org/10.1021/acs.est.7b04180

\section{REFERENCES}

1. Durnford, D.; Dastoor, A.; Figueras-Nieto, D.; Ryjkov, A., Long range transport of mercury to the Arctic and across Canada. Atmos. Chem. Phys. 2010, 10, (13), 6063-6086.

2. Muir, D. C. G.; Wang, X.; Yang, F.; Nguyen, N.; Jackson, T. A.; Evans, M. S.; Douglas, M.; Kock, G.; Lamoureux, S.; Pienitz, R.; Smol, J. P.; Vincent, W. F.; Dastoor, A., Spatial trends and historical deposition of mercury in eastern and northern Canada inferred from lake sediment cores. Environ. Sci. Technol. 2009, 43, (13), 4802-4809.

3. Dastoor, A.; Ryzhkov, A.; Durnford, D.; Lehnherr, I.; Steffen, A.; Morrison, H., Atmospheric mercury in the Canadian Arctic. Part II: Insight from modeling. Sci. Total Environ. 2015, 509-510, 16-27.

4. Gantner, N.; Muir, D. C.; Power, M.; Iqaluk, D.; Reist, J. D.; Babaluk, J. A.; Meili, M.; Borg, H.; Hammar, J.; Michaud, W.; Dempson, B.; Solomon, K. R., Mercury concentrations in landlocked Arctic char (Salvelinus alpinus) from the Canadian Arctic. Part II: Influence of lake biotic and abiotic characteristics on geographic trends in 27 populations. Environ. Toxicol. Chem. 2010, 29, (3), 633-643.

5. $\quad$ van der Velden, S.; Evans, M. S.; Dempson, J. B.; Muir, D. C. G.; Power, M., Comparative analysis of total mercury concentrations in anadromous and non-anadromous Arctic charr (Salvelinus alpinus) from eastern Canada. Sci. Total Environ. 2013, 447, 438-449.

6. $\quad$ Lockhart, W. L.; Stern, G. A.; Low, G.; Hendzel, M.; Boila, G.; Roach, P.; Evans, M. S.; Billeck, B. N.; DeLaronde, J.; Friesen, S.; Kidd, K.; Atkins, S.; Muir, D. C. G.; Stoddart, M.; Stephens, G.; Stephenson, S.; Harbicht, S.; Snowshoe, N.; Grey, B.; Thompson, S.; DeGraff, N., A history of total mercury in edible muscle of fish from lakes in northern Canada. Sci. Total Environ. 2005, 351, 427-463.

7. AMAP, AMAP Assessment 2011: Mercury in the Arctic; Arctic Monitoring and Assessment Programme (AMAP): Oslo, Norway, 2011; p xiv + 193.

8. NCP, Canadian Arctic Contaminants Assessment Report III: Mercury in Canada's North 2012; Northern Contaminants Program (NCP), Aboriginal Affairs and Northern Development Canada: Ottawa, 2012. 
This document is the accepted version of a Submitted Work that was subsequently published in 'Environmental Science \& Technology', copyright @ American Chemical Society after peer review. To access the final edited and published work see: Chételat, J., Richardson, M.C., MacMillan, G.A., Amyot, M. and Poulain, A.J., 2018. Ratio of methylmercury to dissolved organic carbon in water explains methylmercury bioaccumulation across a latitudinal gradient from north-temperate to arctic lakes. Environmental science \& technology, 52(1), pp.79-88. DOI: https://doi.org/10.1021/acs.est.7b04180

468 9. $\quad$ Munthe, J.; Bodaly, R. A.; Branfireun, B. A.; Driscoll, C. T.; Gilmour, C. C.; Harris, R.; 469 Horvat, M.; Lucotte, M.; Malm, O., Recovery of mercury-contaminated fisheries. Ambio 2007, $47036,(1), 33-44$.

471 10. Vincent, W. F.; Hobbie, J. E.; Laybourn-Parry, J., Introduction to the limnology of high472 latitude lake and river ecosystems. In Polar Lakes and Rivers. Limnology of Arctic and Antarctic 473 Aquatic Ecosystems, Vincent, W. F.; Laybourn-Parry, J., Eds. Oxford University Press: Oxford, $474 \quad 2008 ;$ pp 1-23.

475 11. Ravichandran, M., Interactions between mercury and dissolved organic matter - A 476 review. Chemosphere 2004, 55, (3), 319-331.

477 12. Chiasson-Gould, S. A.; Blais, J. M.; Poulain, A., Dissolved organic matter kinetically 478 controls mercury bioavailability to bacteria. Environ. Sci. Technol. 2014, 48, (6), 3153-3161.

479 13. Watras, C. J.; Back, R. C.; Halvorsen, S.; Hudson, R. J. M.; Morrison, K. A.; Wente, S. 480 P., Bioaccumulation of mercury in pelagic freshwater food webs. Sci. Total Environ. 1998, 219, $481 \quad(2-3), 183-208$.

482 14. Gorski, P. R.; Armstrong, D. E.; Hurley, J. P.; Krabbenhoft, D. P., Influence of natural 483 dissolved organic carbon on the bioavailability of mercury to a freshwater alga. Environ. Pollut. 2008, 154, (1), 116-123.

485 15. Tsui, M. T. K.; Finlay, J. C., Influence of dissolved organic carbon on methylmercury 486 bioavailability across minnesota stream ecosystems. Environ. Sci. Technol. 2011, 45, (14), 59814875987.

488 16. Pickhardt, P. C.; Folt, C. L.; Chen, C. Y.; Klaue, B.; Blum, J. D., Algal blooms reduce the 489 uptake of toxic methylmercury in freshwater food webs. Proc. Natl. Acad. Sci. USA 2002, 99, 490 (7), 4419-4423.

491 17. Chen, C. Y.; Folt, C. L., High plankton densities reduce mercury biomagnification. 492 Environ. Sci. Technol. 2005, 39, (1), 115-121.

493 18. Hill, W. R.; Larsen, I. L., Growth dilution of metals in microalgal biofilms. Environ. Sci. 494 Technol. 2005, 39, (6), 1513-1518.

495 19. Hall, B. D.; Bodaly, R. A.; Fudge, R. J. P.; Rudd, J. W. M.; Rosenberg, D. M., Food as 496 the dominant pathway of methylmercury uptake by fish. Water Air and Soil Pollution 1997, 100, 497 (1-2), 13-24. 
This document is the accepted version of a Submitted Work that was subsequently published in 'Environmental Science \& Technology', copyright @ American Chemical Society after peer review. To access the final edited and published work see: Chételat, J., Richardson, M.C., MacMillan, G.A., Amyot, M. and Poulain, A.J., 2018. Ratio of methylmercury to dissolved organic carbon in water explains methylmercury bioaccumulation across a latitudinal gradient from north-temperate to arctic lakes. Environmental science \& technology, 52(1), pp.79-88. DOI: https://doi.org/10.1021/acs.est.7b04180

20. Gantner, N.; Power, M.; Iqaluk, D.; Meili, M.; Borg, H.; Sundbom, M.; Solomon, K. R.; Lawson, G.; Muir, D. C., Mercury concentrations in landlocked Arctic char (Salvelinus alpinus) from the Canadian Arctic. Part I: Insights from trophic relationships in 18 lakes. Environ. Toxicol. Chem. 2010, 29, (3), 621-632.

21. ESRI, World Imagery Map. Original Basemap Sources: ESRI, DigitalGlobe, GeoEye, icubed, Earthstar Geographics, CNES/Airbus DS, USDA, USGS, AEX, Getmapping, Aerogrid, IGN, IGP, swisstopo, and the GIS User Community. Accessed in 2016 using ArcMap 10.4.1 GIS software.

22. Welch, H. E., Ecology of Chironomidae (Diptera) in a polar lake. J. Fish. Res. Board Can. 1976, 33, 227-247.

23. Clayden, M. G.; Kidd, K. A.; Chételat, J.; Hall, B. D.; Garcia, E., Environmental, geographic and trophic influences on methylmercury concentrations in macroinvertebrates from lakes and wetlands across Canada. Ecotoxicology 2014, 23, (2), 273-284.

24. Chételat, J.; Amyot, M.; Garcia, E., Habitat-specific bioaccumulation of methylmercury in invertebrates of small mid-latitude lakes in North America. Environ. Pollut. 2011, 159, (1), 10-17.

25. Hammerschmidt, C. R.; Fitzgerald, W. F., Methylmercury in mosquitoes related to atmospheric mercury deposition and contamination. Environ. Sci. Technol. 2005, 39, (9), 30343039.

26. Hammerschmidt, C. R.; Fitzgerald, W., Methylmercury in freshwater fish linked to atmospheric mercury deposition. Environ. Sci. Technol. 2005, 40, 7764-7770.

27. Harris, R. C.; Rudd, J. W. M.; Amyot, M.; Babiarz, C. L.; Beaty, K. G.; Blanchfield, P. J.; Bodaly, R. A.; Branfireun, B. A.; Gilmour, C. C.; Graydon, J. A.; Heyes, A.; Hintelmann, H.; Hurley, J. P.; Kelly, C. A.; Krabbenhoft, D. P.; Lindberg, S. E.; Mason, R. P.; Paterson, M. J.; Podemski, C. L.; Robinson, A.; Sandilands, K. A.; Southworthn, G. R.; St. Louis, V. L.; Tate, M. T., Whole-ecosystem study shows rapid fish-mercury response to changes in mercury deposition. Proc. Natl. Acad. Sci. USA 2007, 104, (42), 16586-16591.

28. Orihel, D. M.; Paterson, M. J.; Blanchfield, P. J.; Bodaly, R. A.; Hintelmann, H., Experimental evidence of a linear relationship between inorganic mercury loading and methylmercury accumulation by aquatic biota. Environ. Sci. Technol. 2007, 41, (14), 4952-4958. 
This document is the accepted version of a Submitted Work that was subsequently published in 'Environmental Science \& Technology', copyright @ American Chemical Society after peer review. To access the final edited and published work see: Chételat, J., Richardson, M.C., MacMillan, G.A., Amyot, M. and Poulain, A.J., 2018. Ratio of methylmercury to dissolved organic carbon in water explains methylmercury bioaccumulation across a latitudinal gradient from north-temperate to arctic lakes. Environmental science \& technology, 52(1), pp.79-88. DOI: https://doi.org/10.1021/acs.est.7b04180

528 29. Chételat, J.; Amyot, M.; Cloutier, L.; Poulain, A., Metamorphosis in chironomids, more

than mercury supply, controls methylmercury transfer to fish in High Arctic lakes. Environ. Sci. Technol. 2008, 42, (24), 9110-9115.

30. Desrosiers, M.; Planas, D.; Mucci, A., Total mercury and methylmercury accumulation in periphyton of Boreal Shield Lakes: Influence of watershed physiographic characteristics. Sci. Total Environ. 2006, 355, (1-3), 247-258.

31. Rolfhus, K. R.; Hall, B. D.; Monson, B. A.; Paterson, M. J.; Jeremiason, J. D., Assessment of mercury bioaccumulation within the pelagic food web of lakes in the western Great Lakes region. Ecotoxicology 2011, 20, (7), 1520-1529.

32. Walters, D. M.; Raikow, D. F.; Hammerschmidt, C. R.; Mehling, M. G.; Kovach, A.; Oris, J. T., Methylmercury Bioaccumulation in Stream Food Webs Declines with Increasing Primary Production. Environ. Sci. Technol. 2015, 49, (13), 7762-7769.

33. Girard, C.; Leclerc, M.; Amyot, M., Photodemethylation of Methylmercury in Eastern Canadian Arctic Thaw Pond and Lake Ecosystems. Environ. Sci. Technol. 2016, 50, (7), 35113520.

34. Markager, S.; Vincent, W. F.; Tang, E. P. Y., Carbon fixation by phytoplankton in high Arctic lakes: Implications of low temperature for photosynthesis. Limnol. Oceanogr. 1999, 44, (3 I), 597-607.

35. Prowse, T. D.; Wrona, F. J.; Reist, J. D.; Gibson, J. J.; Hobbie, J. E.; Lévesque, L. M. J.; Vincent, W. F., Climate change effects on hydroecology of arctic freshwater ecosystems. Ambio 2006, 35, (7), 347-358.

36. Åkerblom, S.; Nilsson, M.; Yu, J.; Ranneby, B.; Johansson, K., Temporal change estimation of mercury concentrations in northern pike (Esox lucius L.) in Swedish lakes. Chemosphere 2012, 86, (5), 439-445.

37. Chen, C. Y.; Stemberger, R. S.; Kamman, N. C.; Mayes, B. M.; Folt, C. L., Patterns of $\mathrm{Hg}$ bioaccumulation and transfer in aquatic food webs across multi-lake studies in the northeast US. Ecotoxicology 2005, 14, (1-2), 135-147.

38. Rennie, M. D.; Collins, N. C.; Purchase, C. F.; Tremblay, A., Predictive models of benthic invertebrate methylmercury in Ontario and Quebec lakes. Can. J. Fish. Aquat. Sci. 2005, 62, (12), 2770-2783. 
This document is the accepted version of a Submitted Work that was subsequently published in 'Environmental Science \& Technology', copyright @ American Chemical Society after peer review. To access the final edited and published work see: Chételat, J., Richardson, M.C., MacMillan, G.A., Amyot, M. and Poulain, A.J., 2018. Ratio of methylmercury to dissolved organic carbon in water explains methylmercury bioaccumulation across a latitudinal gradient from north-temperate to arctic lakes. Environmental science \& technology, 52(1), pp.79-88. DOI: https://doi.org/10.1021/acs.est.7b04180

39. Driscoll, C. T.; Han, Y. J.; Chen, C. Y.; Evers, D. C.; Lambert, K. F.; Holsen, T. M.; Kamman, N. C.; Munson, R. K., Mercury contamination in forest and freshwater ecosystems in the northeastern United States. BioScience 2007, 57, (1), 17-28.

40. Semkin, R. G.; Mierle, G.; Neureuther, R. J., Hydrochemistry and mercury cycling in a High Arctic watershed. Sci. Total Environ. 2005, 342, (1-3), 199-221.

41. Pan, J. F.; Wang, W. X., Uptake of $\mathrm{Hg}(\mathrm{II})$ and methylmercury by the green mussel Perna viridis under different organic carbon conditions. Mar. Ecol. Prog. Ser. 2004, 276, (1), 125-136. 42. Pinel-Alloul, B.; André, A.; Legendre, P.; Cardille, J. A.; Patalas, K.; Salki, A., Largescale geographic patterns of diversity and community structure of pelagic crustacean zooplankton in Canadian lakes. Global Ecology and Biogeography 2013, 22, (7), 784-795.

43. Chételat, J.; Amyot, M., Elevated methylmercury in High Arctic Daphnia and the role of productivity in controlling their distribution. Global Change Biol. 2009, 15, (3), 706-718.

44. Todorova, S.; Driscoll, C. T.; Matthews, D. A.; Effler, S. W., Zooplankton community changes confound the biodilution theory of methylmercury accumulation in a recovering mercury-contaminated lake. Environ. Sci. Technol. 2015, 49, (7), 4066-4071.

45. Dommergue, A.; Ferrari, C. P.; Poissant, L.; Gauchard, P. A.; Boutron, C. F., Diurnal cycles of gaseous mercury within the snowpack at Kuujjuarapik/Whapmagoostui, Quebec, Canada. Environ. Sci. Technol. 2003, 37, (15), 3289-3297.

46. Poulain, A. J.; Lalonde, J. D.; Amyot, M.; Shead, J. A.; Raofie, F.; Ariya, P. A., Redox transformations of mercury in an Arctic snowpack at springtime. Atmos. Environ. 2004, 38, (39), 6763-6774.

47. St. Louis, V. L.; Hintelmann, H.; Graydon, J. A.; Kirk, J. L.; Barker, J.; Dimock, B.; Sharp, M. J.; Lehnherr, I., Methylated mercury species in Canadian high Arctic marine surface waters and snowpacks. Environ. Sci. Technol. 2007, 41, (18), 6433-6441.

48. St. Pierre, K. A.; St. Louis, V. L.; Kirk, J. L.; Lehnherr, I.; Wang, S.; La Farge, C., Importance of open marine waters to the enrichment of total mercury and monomethylmercury in lichens in the canadian high arctic. Environ. Sci. Technol. 2015, 49, (10), 5930-5938.

49. Soerensen, A. L.; Jacob, D. J.; Schartup, A. T.; Fisher, J. A.; Lehnherr, I.; St Louis, V. L.; Heimbürger, L. E.; Sonke, J. E.; Krabbenhoft, D. P.; Sunderland, E. M., A mass budget for 
This document is the accepted version of a Submitted Work that was subsequently published in 'Environmental Science \& Technology', copyright @ American Chemical Society after peer review. To access the final edited and published work see: Chételat, J., Richardson, M.C., MacMillan, G.A., Amyot, M. and Poulain, A.J., 2018. Ratio of methylmercury to dissolved organic carbon in water explains methylmercury bioaccumulation across a latitudinal gradient from north-temperate to arctic lakes. Environmental science \& technology, 52(1), pp.79-88. DOI: https://doi.org/10.1021/acs.est.7b04180

mercury and methylmercury in the Arctic Ocean. Global Biogeochem. Cy. 2016, 30, (4), 560575.

50. Durnford, D.; Dastoor, A., The behavior of mercury in the cryosphere: A review of what we know from observations. Journal of Geophysical Research D: Atmospheres 2011, 116, (6). 51. Douglas, T. A.; Loseto, L. L.; MacDonald, R. W.; Outridge, P.; Dommergue, A.; Poulain, A.; Amyot, M.; Barkay, T.; Berg, T.; Chetelat, J.; Constant, P.; Evans, M.; Ferrari, C.; Gantner, N.; Johnson, M. S.; Kirk, J.; Kroer, N.; Larose, C.; Lean, D.; Nielsen, T. G.; Poissant, L.; Rognerud, S.; Skov, H.; Sørensen, S.; Wang, F.; Wilson, S.; Zdanowicz, C. M., The fate of mercury in Arctic terrestrial and aquatic ecosystems, a review. Environ. Chem. 2012, 9, (4), 321355.

52. Chételat, J.; Hintelmann, H.; Amyot, M.; Poulain, A.; Girard, C.; Dimock, B.; Iqaluk, P.; Pelletier, P.; Bélanger, D., Production and loss of methylmercury, and its uptake in lake food webs of the High Arctic. In Synopsis of Research Conducted under the 2011-2012 Northern Contaminants Program, Aboriginal Affairs and Northern Development Canada, Government of Canada: Ottawa, 2012; pp 336-350.

53. Lehnherr, I., Methylmercury biogeochemistry: A review with special reference to Arctic aquatic ecosystems. Environ. Rev. 2014, 22, (3), 229-243.

54. Muir, D.; Kock, G.; Kirk, J.; Wang, X., Temporal Trends of Persistent Organic Pollutants and Mercury in Landlocked char in High Arctic Lakes. In Synopsis of Research Conducted under the 2015-2016 Northern Contaminants Program, Indigenous and Northern Affairs Canada, Government of Canada: Ottawa, 2016; pp 249-257.

55. Evans, M.; Muir, D.; Brua, R. B.; Keating, J.; Wang, X., Mercury trends in predatory fish in Great Slave Lake: The influence of temperature and other climate drivers. Environ. Sci. Technol. 2013, 47, (22), 12793-12801.

56. Carrie, J.; Wang, F.; Sanei, H.; Macdonald, R. W.; Outridge, P. M.; Stern, G. A., Increasing contaminant burdens in an Arctic fish, burbot (Lota lota), in a warming climate. Environ. Sci. Technol. 2010, 44, 316-322.

57. Stern, G. A.; Macdonald, R. W.; Outridge, P. M.; Wilson, S.; Chételat, J.; Cole, A.; Hintelmann, H.; Loseto, L. L.; Steffen, A.; Wang, F.; Zdanowicz, C., How does climate change influence arctic mercury? Sci. Total Environ. 2012, 414, 22-42. 
This document is the accepted version of a Submitted Work that was subsequently published in 'Environmental Science \& Technology', copyright $@$ American Chemical Society after peer review. To access the final edited and published work see: Chételat, J., Richardson, M.C., MacMillan, G.A., Amyot, M. and Poulain, A.J., 2018. Ratio of methylmercury to dissolved organic carbon in water explains methylmercury bioaccumulation across a latitudinal gradient from north-temperate to arctic lakes. Environmental science \& technology, 52(1), pp.79-88. DOI: https://doi.org/10.1021/acs.est.7b04180

\section{Figure Headings}

Figure 1. Latitudinal trends in modelled atmospheric mercury deposition (top panel; data from Muir et al. ${ }^{2}$ ) and lake-mean concentrations of water THg and MMHg and sediment THg in the four study regions. Box plot colours correspond to locations on the map. Water $\mathrm{THg}$ and $\mathrm{MMHg}$ concentrations are from the surface layer except for thermally-stratified Gatineau Park lakes where the mean of surface and bottom water concentrations for each lake are presented.

Figure 2. Lake-mean concentrations of MMHg in benthic chironomid larvae and zooplankton in the four study regions. Box plot colours correspond to locations on the map in Figure 1.

Figure 3. PCA correlation biplot showing dominant gradients in surface water chemistry and physical characteristics of lakes spanning $30^{\circ}$ of latitude in eastern Canada. Lakes are identified by study region (Gatineau Park = yellow, Kuujjuaraapik = blue, Iqaluit $=$ orange, Resolute Bay $=$ green). See methods for abbreviations.

Figure 4. The MMHg:DOC ratio of surface water strongly explained the sensitivity of lakes to MMHg bioaccumulation in chironomid larvae $\left(r^{2} a d j=0.70, p<0.001, n=35\right)$ and zooplankton $\left(r^{2} a d j=0.38, p<0.001, n=34\right)$. Note the MMHg:DOC ratio in the right panel is log-transformed.

Figure 5. Relationship between water DOC and MMHg bioaccumulation factors (BAFs) for basal organic matter sources of sub-Arctic and Arctic lakes: rock biofilms $\left(r^{2} a d j=0.51, p<\right.$ $0.001, n=24)$ and seston $\left(r^{2} a d j=0.43, p<0.001, n=22\right)$. Note water DOC in the right panel is log-transformed. 
This document is the accepted version of a Submitted Work that was subsequently published in 'Environmental Science \& Technology', copyright @ American Chemical Society after peer review. To access the final edited and published work see: Chételat, J., Richardson, M.C., MacMillan, G.A., Amyot, M. and Poulain, A.J., 2018. Ratio of methylmercury to dissolved organic carbon in water explains methylmercury bioaccumulation across a latitudinal gradient from north-temperate to arctic lakes. Environmental science \& technology, 52(1), pp.79-88. DOI: https://doi.org/10.1021/acs.est.7b04180

\section{Figure 1}
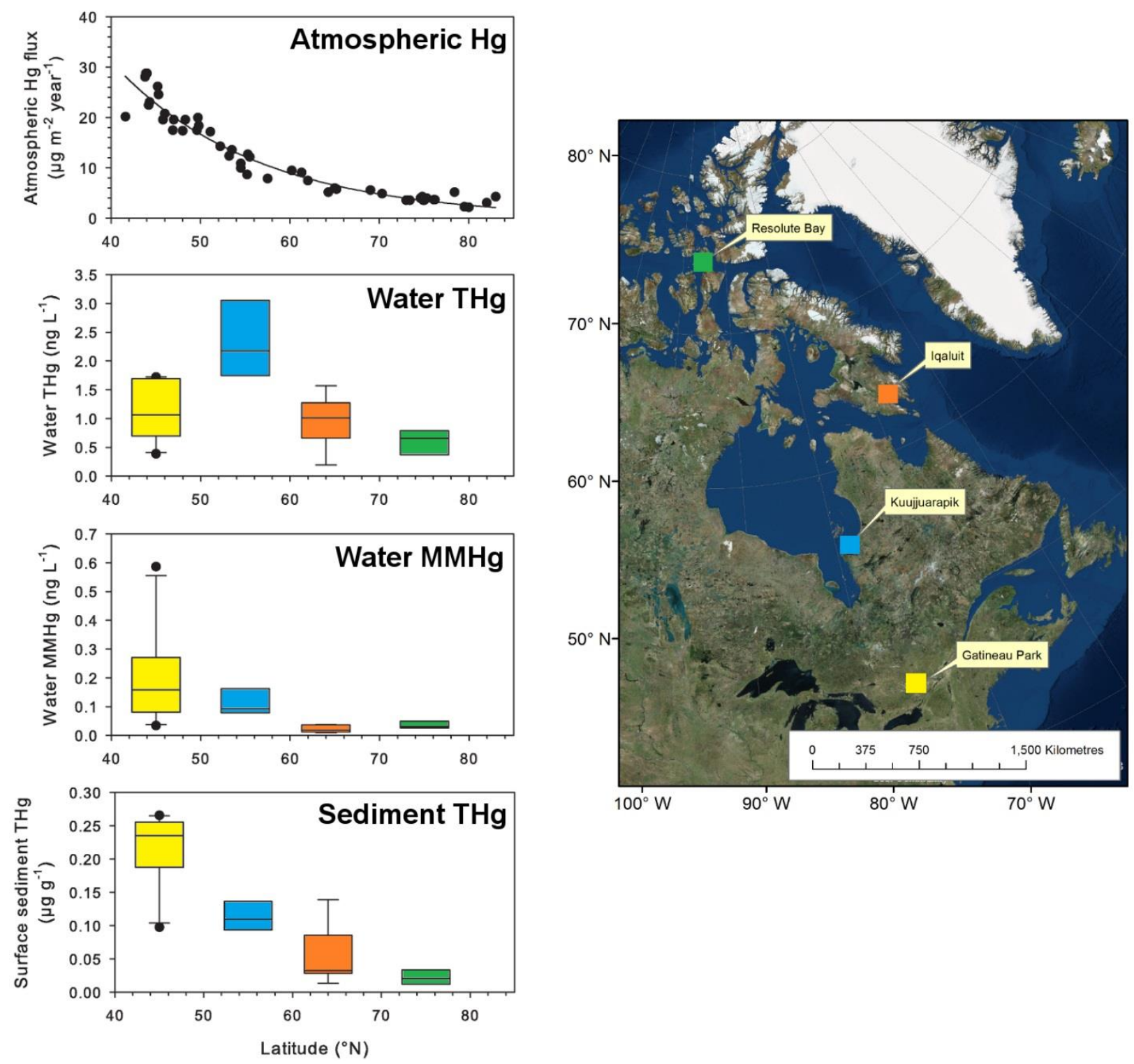
This document is the accepted version of a Submitted Work that was subsequently published in 'Environmental Science \& Technology', copyright @ American Chemical Society after peer review. To access the final edited and published work see: Chételat, J., Richardson, M.C., MacMillan, G.A., Amyot, M. and Poulain, A.J., 2018. Ratio of methylmercury to dissolved organic carbon in water explains methylmercury bioaccumulation across a latitudinal gradient from north-temperate to arctic lakes. Environmental science \& technology, 52(1), pp.79-88. DOI: https://doi.org/10.1021/acs.est.7b04180

\section{Figure 2}
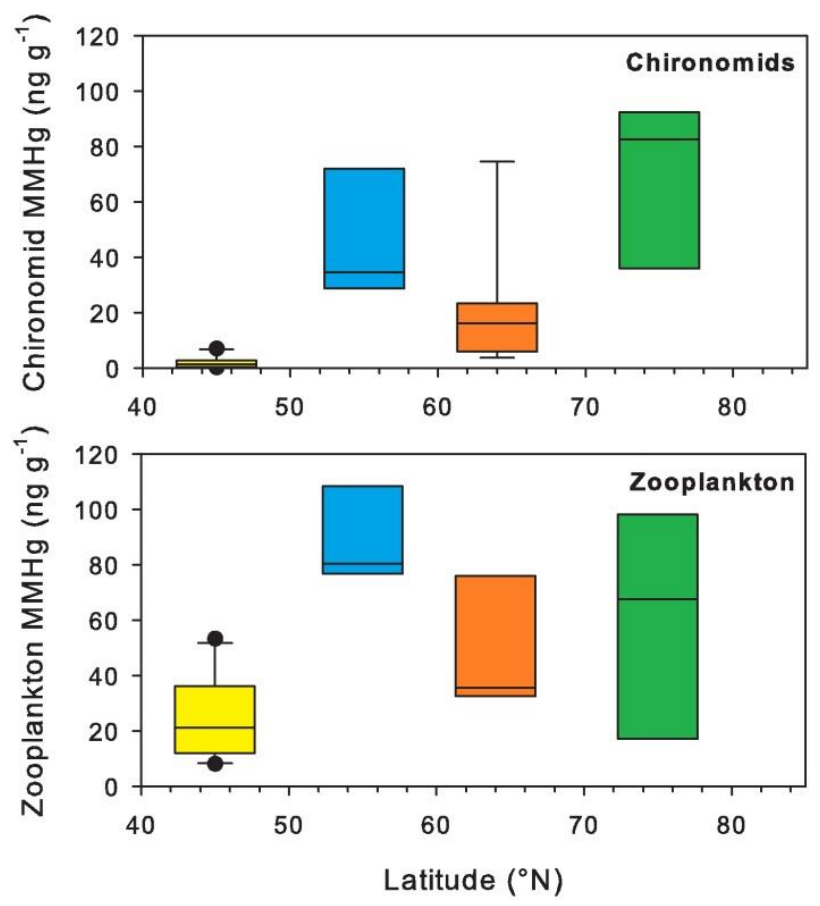
This document is the accepted version of a Submitted Work that was subsequently published in 'Environmental Science \& Technology', copyright @ American Chemical Society after peer review. To access the final edited and published work see: Chételat, J., Richardson, M.C., MacMillan, G.A., Amyot, M. and Poulain, A.J., 2018. Ratio of methylmercury to dissolved organic carbon in water explains methylmercury bioaccumulation across a latitudinal gradient from north-temperate to arctic lakes. Environmental science \& technology, 52(1), pp.79-88. DOI: https://doi.org/10.1021/acs.est.7b04180

Figure 3

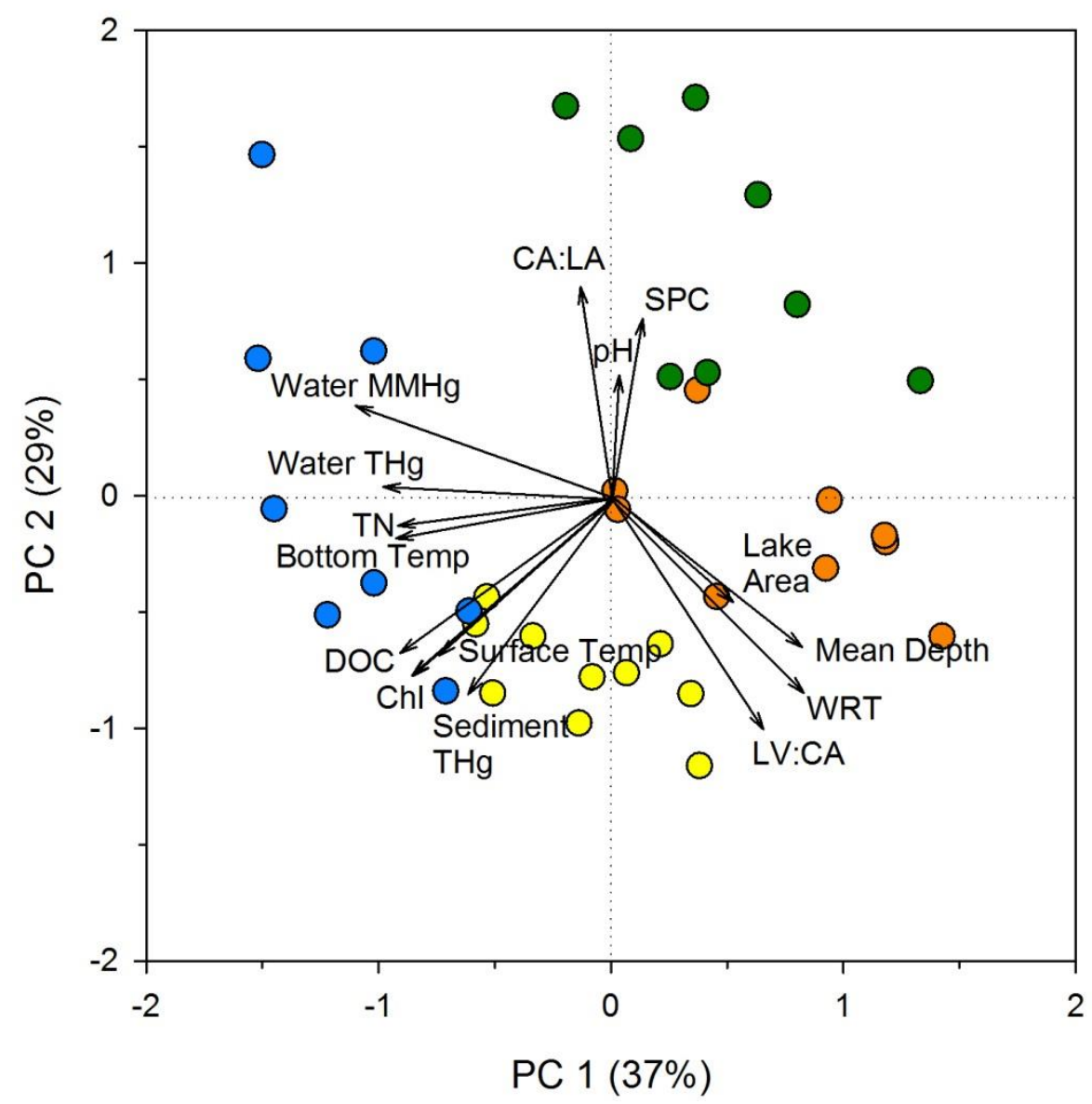


This document is the accepted version of a Submitted Work that was subsequently published in 'Environmental Science \& Technology', copyright @ American Chemical Society after peer review. To access the final edited and published work see: Chételat, J., Richardson, M.C., MacMillan, G.A., Amyot, M. and Poulain, A.J., 2018. Ratio of methylmercury to dissolved organic carbon in water explains methylmercury bioaccumulation across a latitudinal gradient from north-temperate to arctic lakes. Environmental science \& technology, 52(1), pp.79-88. DOI: https://doi.org/10.1021/acs.est.7b04180

\section{Figure 4}
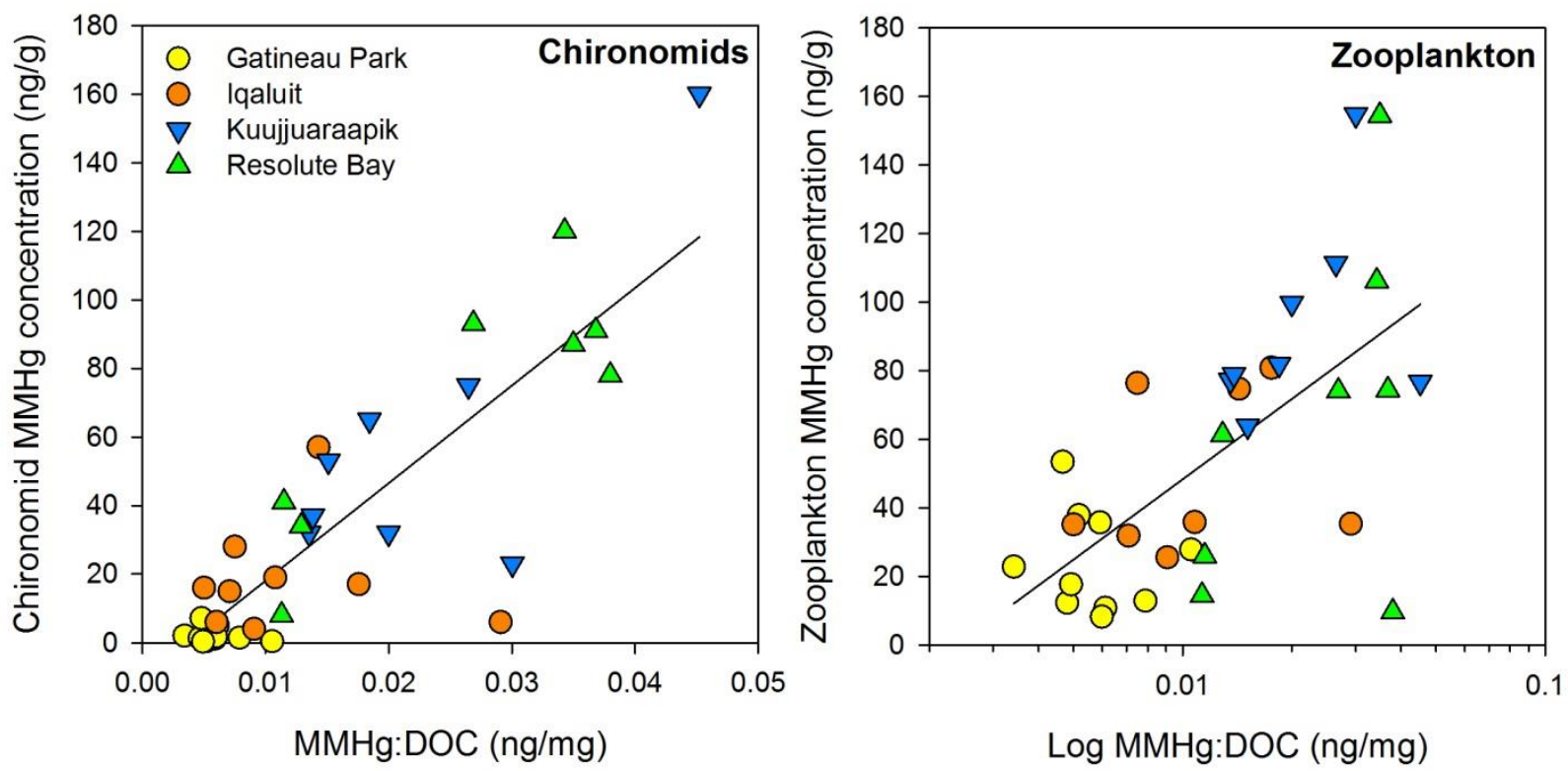
This document is the accepted version of a Submitted Work that was subsequently published in 'Environmental Science \& Technology', copyright @ American Chemical Society after peer review. To access the final edited and published work see: Chételat, J., Richardson, M.C., MacMillan, G.A., Amyot, M. and Poulain, A.J., 2018. Ratio of methylmercury to dissolved organic carbon in water explains methylmercury bioaccumulation across a latitudinal gradient from north-temperate to arctic lakes. Environmental science \& technology, 52(1), pp.79-88. DOI: https://doi.org/10.1021/acs.est.7b04180

\section{Figure 5}
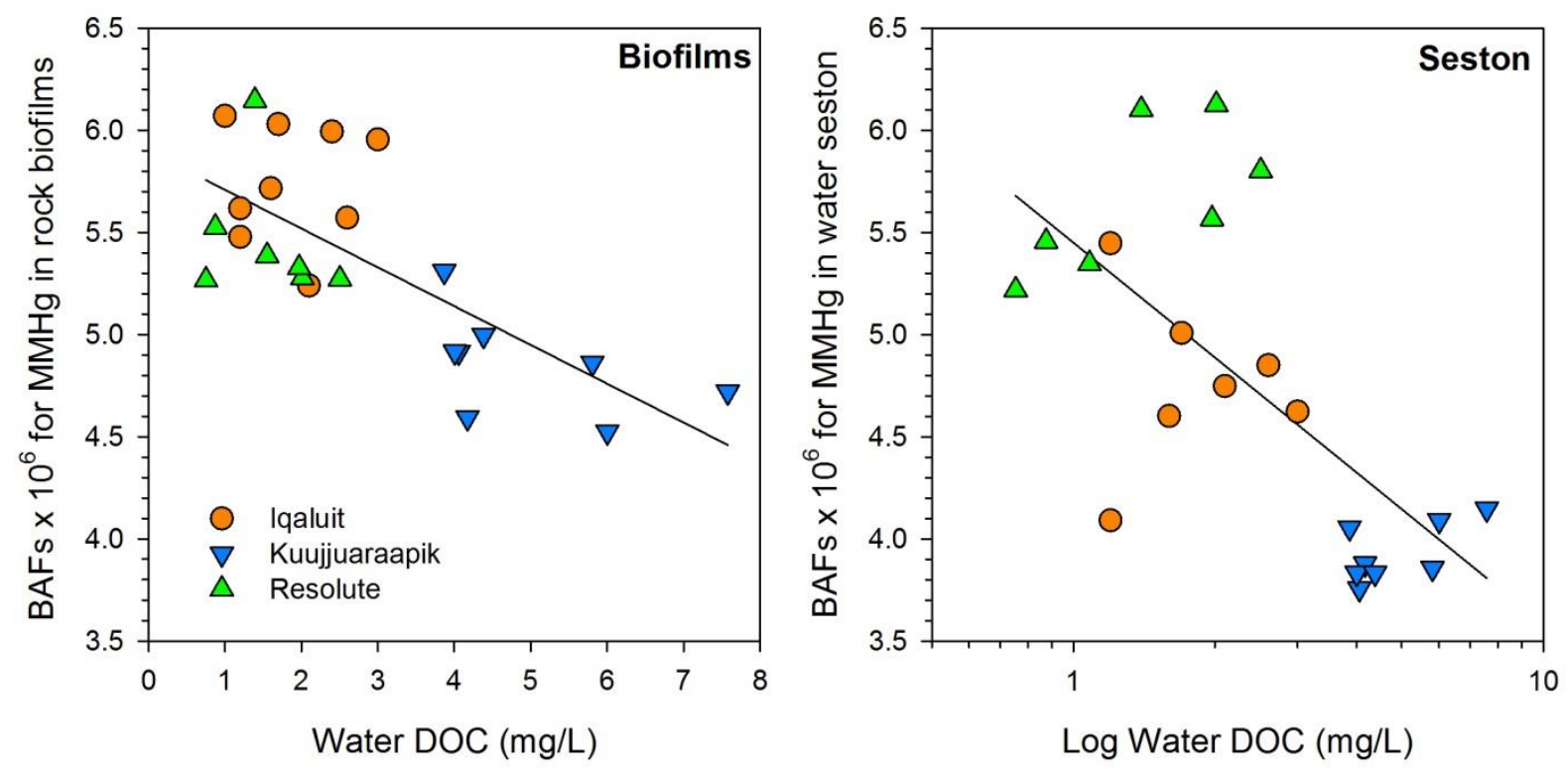
Supporting Information for:

\title{
The ratio of methylmercury to dissolved organic carbon in water explains methylmercury bioaccumulation across a latitudinal gradient from north-temperate to Arctic lakes
}

\author{
John Chételat ${ }^{1}$, Murray C. Richardson ${ }^{2}$, Gwyneth A. MacMillan ${ }^{3}$, Marc Amyot ${ }^{3}$, Alexandre J. \\ Poulain $^{4}$ \\ ${ }^{1}$ National Wildlife Research Centre, Environment and Climate Change Canada, Ottawa, ON, \\ Canada, K1A 0H3 \\ ${ }^{2}$ Geography and Environmental Studies, Carleton University, Ottawa, ON, Canada, K1S 5B6 \\ ${ }^{3}$ Centre d'études nordiques, Département de sciences biologiques, Université de Montréal, \\ Montréal, QC, Canada, H2V 2S9 \\ ${ }^{4}$ Biology, University of Ottawa, Ottawa, ON, Canada, K1N 6N5
}

\section{Corresponding author}

John Chételat

Phone: 613-991-9835; Fax: 613-998-0458; Email: john.chetelat@ canada.ca 


\section{TABLE OF CONTENTS}

Table S1. Location, sampling year, and size of the 35 study lakes. S38

Water Sampling Methods: S39

Figure S1. Comparison of two methods for measurement of chlorophyll concentration in surface water using either an in situ chlorophyll probe or ethanol chlorophyll extraction from filtered seston of six

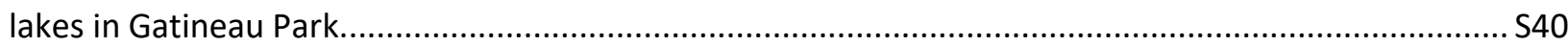

Derivation of Lake and Watershed Morphometrics ..................................................................... S41

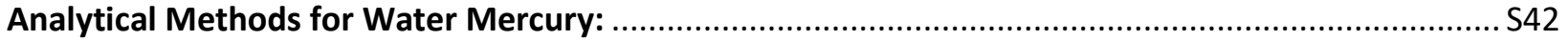

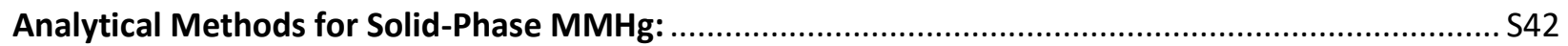

Table S2. Recoveries for THg or MMHg from certified reference materials, precision of duplicate samples (relative standard deviation, RSD), and method detection limits for solid-phase $\mathrm{Hg}$ analysis of various

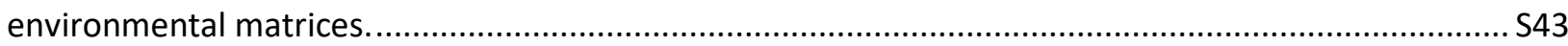

Latitudinal Trend of Surface Sediment THg.

Figure S2. Relationship between lake mean concentration of sediment THg (normalized for organic matter content) and lake depth (regression model: $\mathrm{THg} / \mathrm{N}=5.900+0.501 *$ Mean Depth; $r_{\text {adj }}^{2}=0.31, p<$ $0.001, n=33$ lakes).

Figure S3. Latitudinal trends in modelled atmospheric mercury deposition (solid circles; from Muir et al. $^{3}$ ) and normalized concentrations of THg in surface sediment from lakes in the four study regions. ...45

Table S3. Means and ranges of chemical variables of surface waters, and mercury concentrations of surface sediment and aquatic invertebrates in lakes in the four study regions.

Figure S4. Comparison of surface water (epilimnion) and bottom water (hypolimnion) concentrations of THg (top panel) and MMHg (bottom panel) in stratified Gatineau Park lakes.

Table S4. Multiple regression models explaining $\mathrm{MMHg}$ concentrations of aquatic invertebrates in relation to surface water concentrations of $\mathrm{MMHg}, \mathrm{DOC}, \mathrm{Chl}$ and $\mathrm{TN}$.

Figure S5. Relationship between MMHg concentration in chironomid larvae and the surface water MMHg:DOC ratio ( $r^{2}$ adj $=0.52, p<0.001, n=20$ lakes), following re-analysis of a previously published dataset for the Canadian high Arctic.

Figure S6. Boxplots of $\mathrm{MMHg}$ concentrations in rock biofilms and water seston from lakes in the three Arctic study areas. S50 
Table S1. Location, sampling year, and size of the 35 study lakes.

\begin{tabular}{|c|c|c|c|c|c|c|c|}
\hline Study Area & Lake & Year & Latitude & Longitude & $\begin{array}{l}\text { Lake } \\
\text { Area } \\
\left(\mathrm{km}^{2}\right)\end{array}$ & $\begin{array}{c}\text { Catchment } \\
\text { Area } \\
\left(\mathrm{km}^{2}\right) \\
\end{array}$ & $\begin{array}{c}\text { Mean } \\
\text { Depth } \\
(\mathrm{m})\end{array}$ \\
\hline \multirow{10}{*}{$\begin{array}{l}\text { Gatineau Park } \\
\text { (mixed forest) }\end{array}$} & Black & $2011-12$ & $45^{\circ} 29^{\prime} 30^{\prime \prime}$ & $75^{\circ} 51^{\prime} 51^{\prime \prime}$ & 0.02 & 0.10 & 5.8 \\
\hline & Brown & 2011-12 & $45^{\circ} 36^{\prime} 33^{\prime \prime}$ & $75^{\circ} 55^{\prime} 56^{\prime \prime}$ & 0.27 & 6.24 & 2.9 \\
\hline & Clair & 2011-12 & $45^{\circ} 35^{\prime} 46^{\prime \prime}$ & $76^{\circ} 03^{\prime} 29^{\prime \prime}$ & 0.11 & 0.5 & 13.7 \\
\hline & Kidder & 2011-12 & $45^{\circ} 36^{\prime} 17^{\prime \prime}$ & $76^{\circ} 05^{\prime} 19^{\prime \prime}$ & 0.06 & 1.78 & 9.9 \\
\hline & La Pêche & 2011-12 & $45^{\circ} 37^{\prime} 23^{\prime \prime}$ & $76^{\circ} 11^{\prime} 07^{\prime \prime}$ & 7.06 & 49.4 & 5.7 \\
\hline & Meech & 2011-12 & $45^{\circ} 32^{\prime} 07^{\prime \prime}$ & $75^{\circ} 53^{\prime} 24^{\prime \prime}$ & 2.89 & 60.2 & 13.3 \\
\hline & Phillipe & 2011-12 & $45^{\circ} 36^{\prime} 15^{\prime \prime}$ & $76^{\circ} 00^{\prime} 05^{\prime \prime}$ & 1.75 & 18.1 & 9.1 \\
\hline & Pink & 2011-12 & $45^{\circ} 28^{\prime} 05^{\prime \prime}$ & $75^{\circ} 48^{\prime} 28^{\prime \prime}$ & 0.11 & 0.92 & 11.7 \\
\hline & Ramsay & 2011-12 & $45^{\circ} 35^{\prime} 54^{\prime \prime}$ & $76^{\circ} 05^{\prime} 58^{\prime \prime}$ & 0.11 & 2.71 & 7.1 \\
\hline & Taylor & $2011-12$ & $45^{\circ} 36^{\prime} 17^{\prime \prime}$ & $76^{\circ} 03^{\prime} 04^{\prime \prime}$ & 0.30 & 3.82 & 8 \\
\hline \multirow{8}{*}{$\begin{array}{l}\text { Kuujjjuaraapik- } \\
\text { Whapmagoustui } \\
\text { (sub-Arctic } \\
\text { taiga) }\end{array}$} & Site 1 & 2012 & $55^{\circ} 19^{\prime} 11^{\prime \prime}$ & $77^{\circ} 42^{\prime} 41^{\prime \prime}$ & 0.08 & 2.70 & 0.7 \\
\hline & Site 2 & 2012 & $55^{\circ} 22^{\prime} 10^{\prime \prime}$ & $77^{\circ} 37^{\prime} 04^{\prime \prime}$ & 0.11 & 3.35 & 1.0 \\
\hline & Site 3 & 2012 & $55^{\circ} 18^{\prime} 16^{\prime \prime}$ & $77^{\circ} 42^{\prime} 56^{\prime \prime}$ & 0.01 & 0.62 & 0.3 \\
\hline & Kachishayoot & 2012 & $55^{\circ} 20^{\prime} 03^{\prime \prime}$ & $77^{\circ} 37^{\prime} 31^{\prime \prime}$ & 0.29 & 1.78 & 1.9 \\
\hline & Site 5 & 2012 & $55^{\circ} 17^{\prime} 26^{\prime \prime}$ & $77^{\circ} 43^{\prime} 08^{\prime \prime}$ & 0.05 & 1.00 & 1.3 \\
\hline & Site 6 & 2012 & $55^{\circ} 19^{\prime} 12^{\prime \prime}$ & $77^{\circ} 38^{\prime} 32^{\prime \prime}$ & 0.08 & 0.39 & 0.6 \\
\hline & Site 7 & 2012 & $55^{\circ} 20^{\prime} 01^{\prime \prime}$ & $77^{\circ} 35^{\prime} 48^{\prime \prime}$ & 0.39 & 2.31 & 0.9 \\
\hline & Site 8 & 2012 & $55^{\circ} 20^{\prime} 14^{\prime \prime}$ & $77^{\circ} 36^{\prime} 42^{\prime \prime}$ & 0.10 & 0.19 & 1.2 \\
\hline \multirow{9}{*}{$\begin{array}{l}\text { lqaluit } \\
\text { (tundra) }\end{array}$} & Site 1 & 2013 & $63^{\circ} 47^{\prime} 49^{\prime \prime}$ & $68^{\circ} 32^{\prime} 46^{\prime \prime}$ & 0.03 & 0.21 & 1.8 \\
\hline & Site 2 & 2013 & $63^{\circ} 45^{\prime} 29^{\prime \prime}$ & $68^{\circ} 26^{\prime} 38^{\prime \prime}$ & 0.08 & 2.00 & 6 \\
\hline & Site 3 & 2013 & $63^{\circ} 39^{\prime} 07^{\prime \prime}$ & $68^{\circ} 17^{\prime} 49^{\prime \prime}$ & 0.28 & 4.03 & 12 \\
\hline & Site 4 & 2013 & $63^{\circ} 47^{\prime} 53^{\prime \prime}$ & $68^{\circ} 32^{\prime} 17^{\prime \prime}$ & 0.09 & 0.37 & 5 \\
\hline & Site 5 & 2013 & $63^{\circ} 44^{\prime} 56^{\prime \prime}$ & $68^{\circ} 23^{\prime} 53^{\prime \prime}$ & 0.36 & 1.87 & 6 \\
\hline & Site 6 & 2013 & $63^{\circ} 54^{\prime} 58^{\prime \prime}$ & $68^{\circ} 34^{\prime} 23^{\prime \prime}$ & 0.42 & 12.5 & 3 \\
\hline & lqalugaajuruluit & 2013 & $63^{\circ} 41^{\prime} 06^{\prime \prime}$ & $68^{\circ} 22^{\prime} 34^{\prime \prime}$ & 0.54 & 3.74 & 8 \\
\hline & Site 8 & 2013 & $63^{\circ} 49^{\prime} 30^{\prime \prime}$ & $68^{\circ} 36^{\prime} 14^{\prime \prime}$ & 0.56 & 14.2 & 12 \\
\hline & Tasirluk (Crazy) & 2014 & $63^{\circ} 52^{\prime 29 "}$ & $68^{\circ} 28^{\prime} 40^{\prime \prime}$ & 4.5 & 41.1 & 7.5 \\
\hline \multirow{8}{*}{$\begin{array}{l}\text { Resolute Bay } \\
\text { (polar desert) }\end{array}$} & Ruins & 2014 & $74^{\circ} 40^{\prime} 48^{\prime \prime}$ & $94^{\circ} 54^{\prime} 52^{\prime \prime}$ & 0.13 & 20.2 & 1.8 \\
\hline & Meretta & 2014 & $74^{\circ} 41^{\prime} 24^{\prime \prime}$ & $94^{\circ} 59^{\prime} 24^{\prime \prime}$ & 0.27 & 5.18 & 3.1 \\
\hline & $\mathrm{RZ2}$ & 2014 & $74^{\circ} 43^{\prime} 15^{\prime \prime}$ & $94^{\circ} 51^{\prime} 42^{\prime \prime}$ & 0.03 & 1.51 & 0.8 \\
\hline & Teardrop & 2014 & $74^{\circ} 41^{\prime} 03^{\prime \prime}$ & $94^{\circ} 59^{\prime} 22^{\prime \prime}$ & 0.04 & 0.42 & 4.3 \\
\hline & Small & 2014 & $74^{\circ} 45^{\prime} 33^{\prime \prime}$ & $95^{\circ} 03^{\prime} 37^{\prime \prime}$ & 0.15 & 1.56 & 2.7 \\
\hline & North & 2014 & $74^{\circ} 46^{\prime} 37^{\prime \prime}$ & $95^{\circ} 05^{\prime} 47^{\prime \prime}$ & 0.63 & 83.7 & 6.7 \\
\hline & Resolute & 2014 & $74^{\circ} 41^{\prime} 15^{\prime \prime}$ & $94^{\circ} 56^{\prime} 33^{\prime \prime}$ & 1.21 & 19.8 & 9 \\
\hline & RZ-P3 & 2014 & $74^{\circ} 44^{\prime} 38^{\prime \prime}$ & $94^{\circ} 57^{\prime} 18^{\prime \prime}$ & 0.04 & 1.40 & 0.8 \\
\hline
\end{tabular}




\section{Water Sampling Methods:}

At each lake, in situ water temperature, specific conductivity, $\mathrm{pH}$, and dissolved oxygen were measured with a YSI multi-parameter sonde (YSI Inc., Yellow Springs, Ohio, USA). In Gatineau Park lakes, in situ chlorophyll (Chl) was measured with a YSI fluorescence probe, validated with Chl analyses by ethanol extraction of filtered seston in the laboratory for a subset of six lakes (Supplemental Figure S1). Water for mercury analysis was collected using clean protocols for trace metals (e.g., clean hands/dirty hands method, acid washing of sampling equipment). Surface water was collected as sub-surface grabs in Nalgene® PETG bottles for mercury analysis and in HDPE bottles for analysis of dissolved organic carbon (DOC), total nitrogen (TN), and Chl. Lakes in the Arctic study areas were not stratified or only weakly stratified, and surface grab samples were representative of water column concentrations. Five lakes at Resolute Bay were partially ice covered during sampling in July 2014. For those lakes, water was collected as surface grabs from the ice moat (open water area) and under the ice pan by drilling a hole through the ice to collect water at $4 \mathrm{~m}$ depth with a peristaltic pump and acid-washed teflon tubing. Water THg and MMHg concentrations reported for those partially ice-covered lakes are the means of the surface grab and under ice measurements, which were similar in concentration. In thermally stratified lakes at Gatineau Park, deep hypolimnetic waters (1 $\mathrm{m}$ above the sediments) were sampled for water chemistry by peristaltic pump and acid-washed teflon tubing or by acid-washed teflon Kemmerer bottle. Total and filtered $(0.45$ or $0.7 \mu \mathrm{m})$ water samples were collected for mercury analysis, preserved with ultra-pure $\mathrm{HCl}(0.4 \%$ by volume) and refrigerated. 


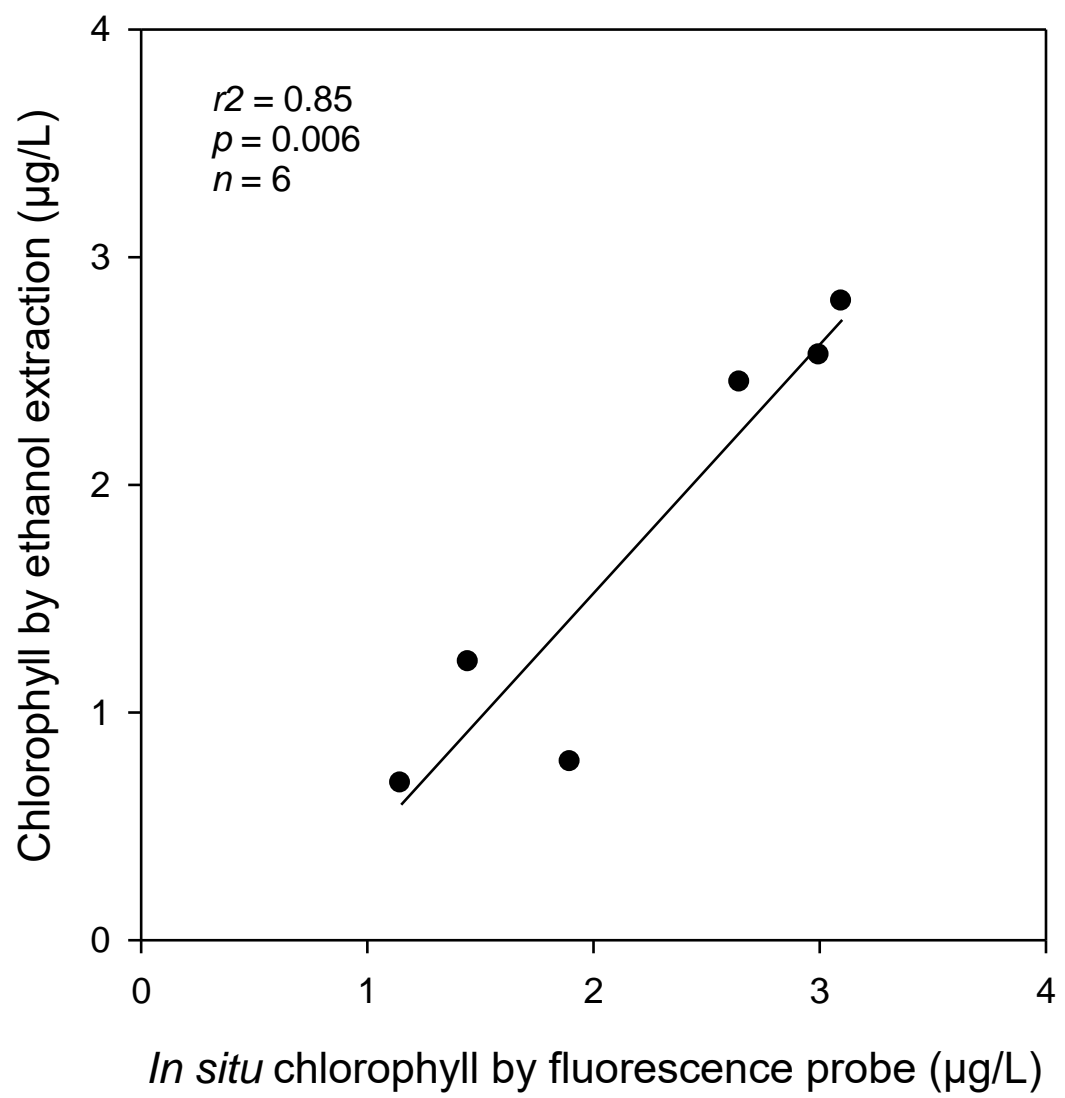

Figure S1. Comparison of two methods for measurement of chlorophyll concentration in surface water using either an in situ chlorophyll probe or ethanol chlorophyll extraction from filtered seston of six lakes in Gatineau Park. Data points are lake-mean estimates of surface water chlorophyll concentration that were calculated with 2 to 10 measurements in each lake. 


\section{Derivation of Lake and Watershed Morphometrics}

Lake and watershed morphometrics including lake area, lake depth, catchment area to lake area ratio (CA:LA) and water residence time (WRT) were determined using GIS-based terrain analysis methods. The bathymetry of each water body was measured in a boat using a GPSlinked echosounder. Lake areas were obtained from 1:50,000 scale CANVEC National Vector hydrography dataset and the catchment area (or gross drainage area) for each water body was extracted from a hydrologically pre-processed, 1:50,000 Canadian Digital Elevation Data (CDED) Digital Elevation Model using well-established methods within the System for Automated Geoscientific Analysis (SAGA) GIS software. ${ }^{1}$ The water residence time of a water body is determined by the ratio of annual discharge volume $\left(\mathrm{q}, \mathrm{m}^{3} \mathrm{yr}^{-1} 1\right)$ entering or exiting the lake to the total volume $\left(\mathrm{V}, \mathrm{m}^{3}\right)$ of the water body itself. ${ }^{2}$ Since data on annual discharge were not available for the study lakes, we estimated it using mean mean annual runoff (MAR) from the landscape for each of the four study regions combined with the catchment area of each lake. MAR was estimated using Water Survey of Canada discharge records for nearby rivers at each site and normalizing to the associated catchment area. Combining this estimate with watershed area (A_ws), lake area (A_lk) and average lake depth (D_lk) for each waterbody (all in units of $\mathrm{m}$ or $\mathrm{m}^{2}$ ), WRT in days was calculated as follows):

$\mathrm{WRT}($ days $)=(\mathrm{V} / \mathrm{q})=\left(\left(\mathrm{A} \_\mathrm{lk} * \mathrm{D} \_\mathrm{lk}\right) /\left(\left(\mathrm{A} \_\mathrm{ws}+\mathrm{A} \_l \mathrm{lk}\right) *(\mathrm{MAR}) / 1000\right)\right) * 365$

LV:CA is a proxy for WRT that assumes constant MAR. Within any one of the four study regions, the information content of $\mathrm{LV}: \mathrm{CA}$ is equivalent to WRT since MAR is a constant. Across the four study sites, the estimation of MAR is incorporated to improve the estimate of WRT. Finally, CA:LA is a simpler, and more commonly used morphometric that can be calculated in the absence of both MAR and lake depth. 
Analytical Methods for Water Mercury: Water samples for MMHg analysis were predistilled with additions of $\mathrm{KCl}$ and $\mathrm{H}_{2} \mathrm{SO}_{4}$ to remove matrix interferences. $\mathrm{MMHg}$ extract was derivatized by aqueous ethylation using $\mathrm{NaBEt}_{4}$, trapped with Tenax and measured with a Tekran 2700 (Tekran® Instruments Corporation, Toronto, Canada) cold vapor atomic fluorescence spectrometer (CVAFS) with a detection limit of $0.01 \mathrm{ng} \mathrm{L}^{-1}$. Relative standard deviations (RSDs) for field and analytical duplicates were $5.5 \pm 5.8 \%(n=64)$ and $7.5 \pm 5.8 \%(n=13)$, respectively. A MMHg standard spiked in Milli-Q water was analyzed after every 12 samples during water $\mathrm{MMHg}$ analyses with a recovery of $97.6 \pm 11.6 \%(n=37)$. Tort- 2 was used as a standard (added to Milli-Q water) to verify the distillation method and potential matrix interferences associated with the presence of organic matter in the water. Recoveries of the distilled Tort- 2 additions in water were $103 \pm 7.8 \%(n=43)$.

Water total mercury ( $\mathrm{THg}$ ) was determined on $50 \mathrm{~mL}$ samples by $\mathrm{BrCl}$ oxidation, $\mathrm{SnCl}_{2}$ reduction, two-stage gold amalgamation and gas-phase detection with a Tekran 2600 CVAFS with a detection limit of $0.05 \mathrm{ng} \mathrm{L}^{-1}$. RSDs of field and analytical duplicates were $2.12 \pm 3.2 \%$ ( $n$ $=64)$ and $1.9 \pm 5.0 \%(n=14)$, respectively. The average recovery of a standard spike for total mercury was $100 \% \pm 4.2 \%(n=43)$. In addition, internal reference waters of known concentration (inter-laboratory calibration solutions) were analyzed for total mercury after every 12 water samples with a recovery of $105 \% \pm 10.7 \%(n=34)$.

Analytical Methods for Solid-Phase MMHg: Freeze-dried and homogenized samples of chironomid larvae $(n=84)$ and biofilm organic matter $(n=70)$ from Arctic lakes were analyzed for MMHg at the Laboratory for the Analysis of Natural and Commercial Environmental Toxins (LANCET, University of Ottawa, Ottawa, Canada). Sample masses of 1-10 mg (chironomids) or 30-100 mg (biofilm organic matter) were pretreated with an alkaline digestion in $\mathrm{KOH}$ followed by acidic digestion in $\mathrm{KBr}$ and $\mathrm{CuSO} 4$. Bromide derivative of $\mathrm{MMHg}$ was extracted in dichloromethane, isolated with sodium thiosulfate and back extracted in dichloromethane for determination by capillary gas chromatography coupled with atomic fluorescence spectrometry. Concentrations of MMHg in chironomid larvae from Gatineau Park $(n=38)$ and all seston $(n=$ $48)$ and zooplankton $(n=55)$ samples were determined at the Laboratoire de biogéochimie environnementale (Université de Montréal, Montreal, Canada). For those samples, MMHg was extracted from sample masses of 1-10 mg (chironomids), $0.5-2 \mathrm{mg}$ (seston) or 3-30 mg (zooplankton) by digestion in $4 \mathrm{M} \mathrm{HNO}_{3}$ at $55^{\circ} \mathrm{C}$ for $16 \mathrm{~h}$, derivatized by aqueous ethylation using NaBEt 4 , trapped with Tenax and measured with a Tekran 2700 CVAFS. 
Table S2. Recoveries for THg or MMHg from certified reference materials, precision of duplicate samples (relative standard deviation, RSD), and method detection limits for solid-phase $\mathrm{Hg}$ analysis of various environmental matrices.

\begin{tabular}{|c|c|c|c|c|c|}
\hline $\begin{array}{l}\text { Sample } \\
\text { Type }\end{array}$ & $\begin{array}{l}\text { Hg Analysis } \\
\text { Method }\end{array}$ & $\begin{array}{l}\text { CRM } \\
\text { Analyzed }\end{array}$ & $\%$ Recovery of $\mathrm{Hg}$ & $\begin{array}{l}\text { Sample } \\
\text { Duplicate } \\
\text { RSD }\end{array}$ & $\begin{array}{l}\text { Method } \\
\text { Detection } \\
\text { Limit }\end{array}$ \\
\hline Sediment & $\begin{array}{l}\text { Direct mercury } \\
\text { analyzer }\end{array}$ & MESS-3 & THg: $97 \pm 7 \%(n=12)$ & $\begin{array}{l}2 \pm 2 \% \\
(n=8)\end{array}$ & $\begin{array}{l}0.2 \mathrm{ng} \text { of } \\
\mathrm{Hg}\end{array}$ \\
\hline $\begin{array}{l}\text { Chironomid } \\
\text { (Arctic), rock } \\
\text { biofilm }\end{array}$ & $\begin{array}{l}\text { Alkaline digestion in } \\
\mathrm{KOH} \text { followed by } \\
\text { acidic digestion in } \\
\mathrm{KBr} \text { and CuSO } 4 \text {, } \\
\text { extraction with } \\
\text { dichloromethane, } \\
\text { detection by GC- } \\
\text { AFS }\end{array}$ & $\begin{array}{l}\text { TORT-2 } \\
\text { DORM-4 }\end{array}$ & $\begin{array}{l}\text { MMHg: } 100 \pm 5 \%(n=17) \\
\text { MMHg: } 94 \pm 7 \%(n=17)\end{array}$ & $\begin{array}{l}5 \pm 4 \% \\
(n=19)\end{array}$ & $\begin{array}{l}3 \mathrm{ng} / \mathrm{g} \text { (for } \\
5 \mathrm{mg} \\
\text { invertebrate } \\
\text { sample) }\end{array}$ \\
\hline Seston & $\begin{array}{l}\text { Nitric acid } \\
\text { digestion, aqueous } \\
\text { ethylation, } \\
\text { detection by } \\
\text { CVAFS }\end{array}$ & TORT-2 & MMHg: $100 \pm 13 \%(n=12)$ & $\begin{array}{l}\text { Insufficient } \\
\text { sample to } \\
\text { do } \\
\text { analytical } \\
\text { duplicates }\end{array}$ & $\begin{array}{l}0.4 \mathrm{ng} / \mathrm{g} \\
\text { (for } 1 \mathrm{mg} \text { of } \\
\text { seston } \\
\text { sample) }\end{array}$ \\
\hline $\begin{array}{l}\text { Zooplankton, } \\
\text { chironomid } \\
\text { (north- } \\
\text { temperate) }\end{array}$ & $\begin{array}{l}\text { Nitric acid } \\
\text { digestion, aqueous } \\
\text { ethylation, } \\
\text { detection by } \\
\text { CVAFS }\end{array}$ & TORT-2 & MMHg: $113 \pm 7 \%(n=22)$ & $\begin{array}{l}13 \pm 10 \% \\
(n=22)\end{array}$ & $\begin{array}{l}0.09 \mathrm{ng} / \mathrm{g} \\
\text { (for } 5 \mathrm{mg} \\
\text { invertebrate } \\
\text { sample) }\end{array}$ \\
\hline
\end{tabular}




\section{Latitudinal Trend of Surface Sediment THg}

Surface sediment THg concentrations were normalized for organic matter content using percent nitrogen $(\% \mathrm{~N})$, which declined with latitude. Means ( \pm 1 standard deviation) of $\% \mathrm{~N}$ in surface sediment from each study area were: $1.9 \pm 0.5 \%$ (Gatineau Park), $1.8 \pm 0.3 \%$ (Kuujjuaraapik), $0.7 \pm 0.4 \%$ (Iqaluit), and $0.6 \pm 0.5 \%$ (Resolute Bay). After normalizing for organic matter content $(\% \mathrm{~N})$, lake-mean concentrations of sediment $\mathrm{THg}$ were positively correlated with lake depth (Figure S2).

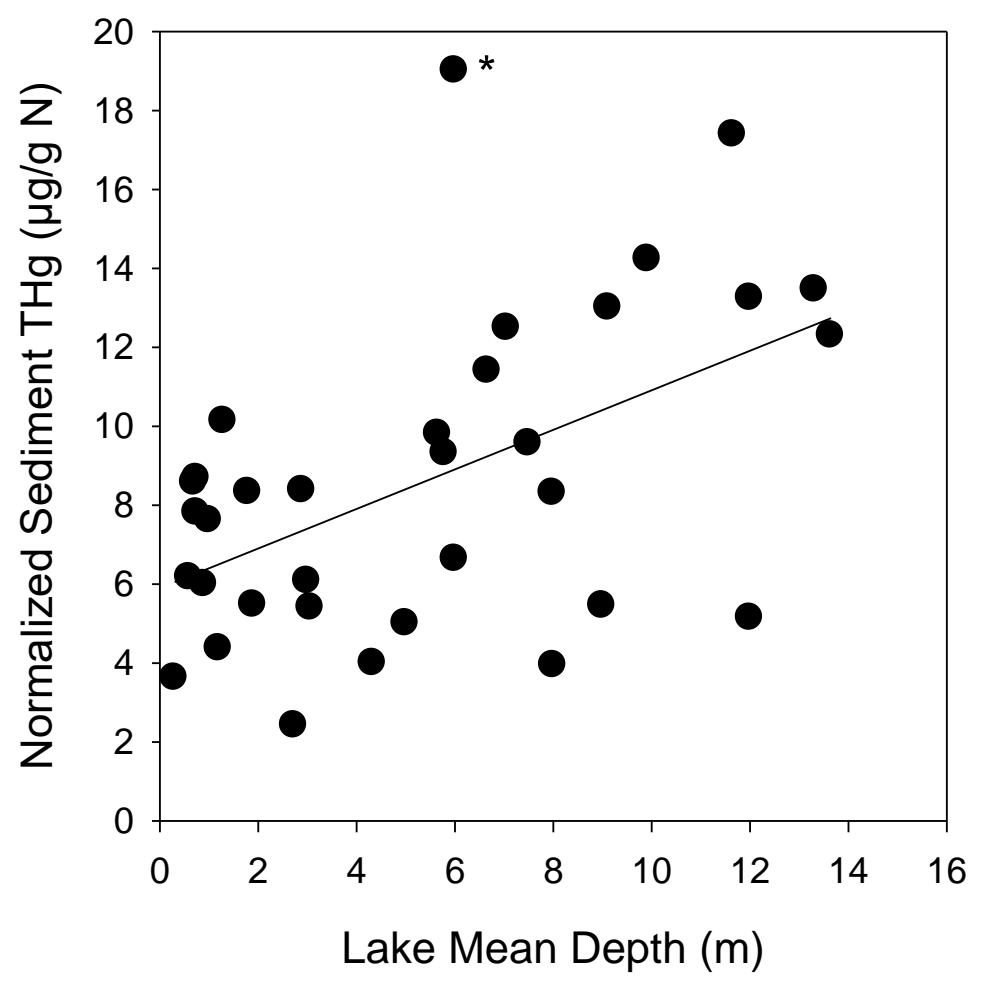

Figure S2. Relationship between lake mean concentration of sediment THg (normalized for nitroge content) and lake depth (regression model: $\mathrm{THg} / \mathrm{N}=5.900+0.501 *$ Mean Depth; $r^{2}{ }_{\text {adj }}=$ $0.31, p<0.001, n=33$ lakes). Note that 1 outlier (identified by the asterix) was removed for the regression model. 
After controlling for both organic matter content $(\% \mathrm{~N})$ and lake mean depth, surface sediment $\mathrm{THg}$ concentrations declined with latitude (Figure S3), similar to the trend for uncorrected $\mathrm{THg}$ concentrations presented in Figure 1. A multiple regression model including both lake mean depth and latitude was highly significant (regression model: $\mathrm{THg} / \mathrm{N}=13.902+(0.391 *$ Mean Depth) - (0.132* Latitude); $r_{a d j}^{2}=0.44, p<0.001, n=33$ lakes $)$.

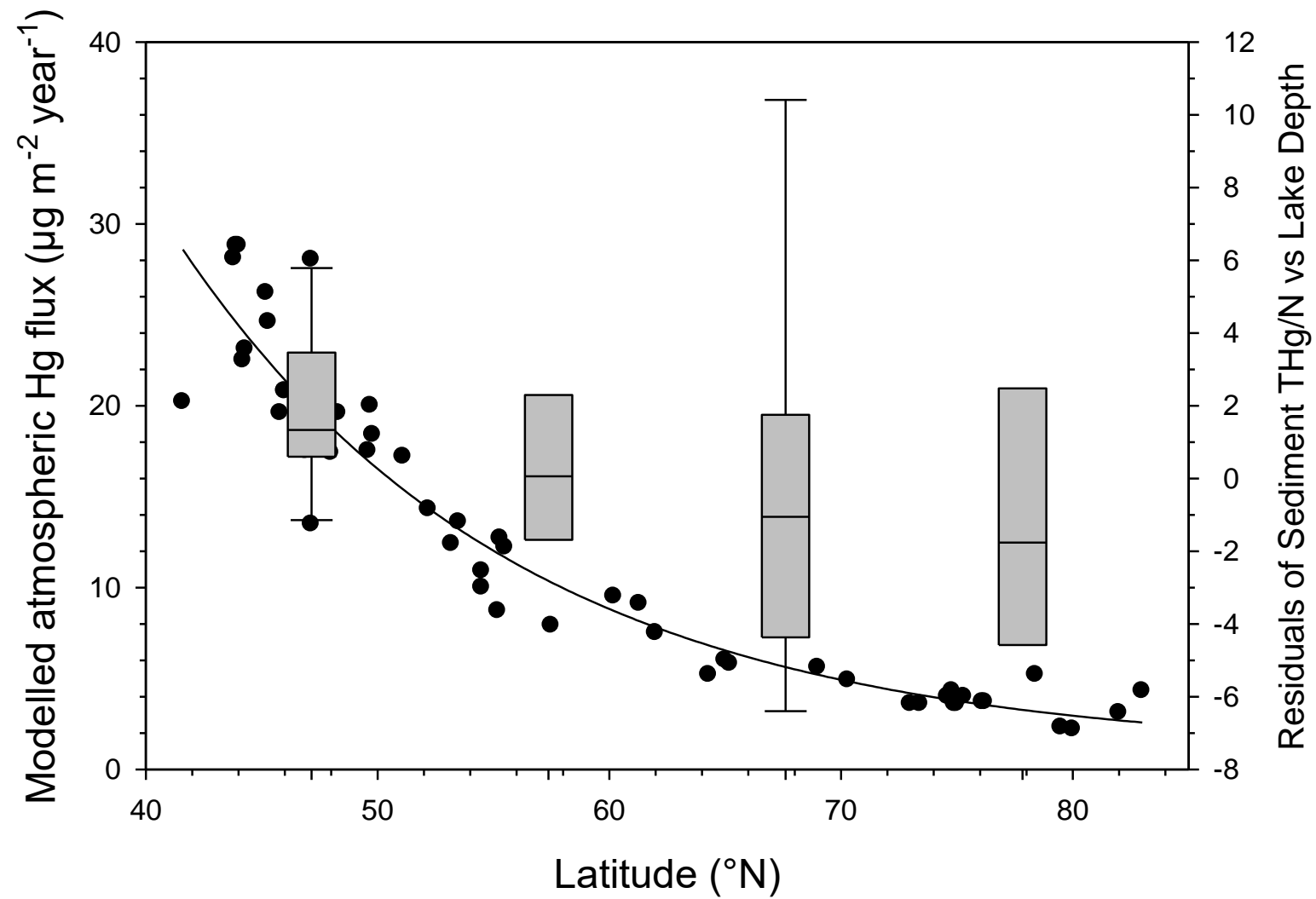

Figure S3. Latitudinal trends in modelled atmospheric mercury deposition (solid circles; from Muir et al. ${ }^{3}$ ) and normalized concentrations of $\mathrm{THg}$ in surface sediment from lakes in the four study regions. 
Table S3. Means and ranges of chemical variables of surface waters, and mercury concentrations of surface sediment and aquatic invertebrates in lakes in the four study regions.

\begin{tabular}{|c|c|c|c|c|c|c|c|c|c|c|c|}
\hline \multirow[b]{2}{*}{ Region } & \multirow[b]{2}{*}{ Descriptor } & \multicolumn{7}{|c|}{ Surface Water } & \multirow{2}{*}{$\begin{array}{c}\text { Sediment } \\
\mathrm{THg} \\
(\mu \mathrm{g} / \mathrm{g})\end{array}$} & \multicolumn{2}{|c|}{ Biotic MMHg } \\
\hline & & $\begin{array}{l}\text { DOC } \\
(\mathrm{mg} / \mathrm{L})\end{array}$ & $\begin{array}{c}\mathrm{TP} \\
(\mu \mathrm{g} / \mathrm{L})\end{array}$ & $\begin{array}{c}\mathrm{TN} \\
(\mathrm{mg} / \mathrm{L}) \\
\end{array}$ & $\begin{array}{c}\mathrm{Chl} \\
(\mu \mathrm{g} / \mathrm{L})\end{array}$ & $\begin{array}{c}\mathrm{THg} \\
\text { (ng/L) }\end{array}$ & $\begin{array}{l}\mathrm{MMHg} \\
(\mathrm{ng} / \mathrm{L})\end{array}$ & $\begin{array}{c}\% \\
\mathrm{MMHg} \\
\end{array}$ & & $\begin{array}{c}\text { Chironomids } \\
\text { (ng/g) }\end{array}$ & $\begin{array}{c}\text { Zooplankton } \\
\text { (ng/g) }\end{array}$ \\
\hline $\begin{array}{l}\text { Gatineau Park }\left(46^{\circ} \mathrm{N}\right) \\
(n=10 \text { lakes })\end{array}$ & $\begin{array}{l}\text { Mean } \\
\text { Range }\end{array}$ & $\begin{array}{c}4.9 \\
3.2-6.7\end{array}$ & --- & $\begin{array}{c}0.21 \\
0.14-0.29\end{array}$ & $\begin{array}{c}1.8 \\
1.2-3.0\end{array}$ & $\begin{array}{c}0.83 \\
0.38-1.37\end{array}$ & $\begin{array}{c}0.03 \\
0.01-0.07\end{array}$ & $\begin{array}{c}4 \\
2-9\end{array}$ & $\begin{array}{c}0.22 \\
0.10-0.27\end{array}$ & $\begin{array}{c}2 \\
0.3-7\end{array}$ & $\begin{array}{c}24 \\
8-53\end{array}$ \\
\hline $\begin{array}{l}\text { Kuujjuaraapik }\left(55^{\circ} \mathrm{N}\right) \\
(n=8 \text { lakes })\end{array}$ & $\begin{array}{l}\text { Mean } \\
\text { Range }\end{array}$ & $\begin{array}{c}5.0 \\
3.9-7.6\end{array}$ & $\begin{array}{c}6.3 \\
3.1-8.7\end{array}$ & $\begin{array}{c}0.27 \\
0.21-0.34\end{array}$ & $\begin{array}{c}1.9 \\
0.8-2.9\end{array}$ & $\begin{array}{c}2.30 \\
1.23-3.09\end{array}$ & $\begin{array}{c}0.11 \\
0.06-0.18\end{array}$ & $\begin{array}{c}5 \\
3-6\end{array}$ & $\begin{array}{c}0.11 \\
0.05-0.14\end{array}$ & $\begin{array}{c}60 \\
23-160\end{array}$ & $\begin{array}{c}93 \\
64-155\end{array}$ \\
\hline $\begin{array}{l}\text { Iqaluit }\left(64^{\circ} \mathrm{N}\right) \\
(n=9 \text { lakes })\end{array}$ & $\begin{array}{l}\text { Mean } \\
\text { Range }\end{array}$ & $\begin{array}{c}1.9 \\
1.0-3.0\end{array}$ & $\begin{array}{c}4.7 \\
1.2-9.6\end{array}$ & $\begin{array}{c}0.08 \\
0.04-0.17\end{array}$ & $\begin{array}{c}0.5 \\
0.2-1.2\end{array}$ & $\begin{array}{c}0.95 \\
0.19-1.57\end{array}$ & $\begin{array}{c}0.02 \\
<0.01-0.04\end{array}$ & $\begin{array}{c}2 \\
1-4\end{array}$ & $\begin{array}{c}0.06 \\
0.01-0.14\end{array}$ & $\begin{array}{c}19 \\
4-57\end{array}$ & $\begin{array}{c}49 \\
26-81\end{array}$ \\
\hline $\begin{array}{l}\text { Resolute Bay }\left(75^{\circ} \mathrm{N}\right) \\
(n=8 \text { lakes })\end{array}$ & $\begin{array}{l}\text { Mean } \\
\text { Range }\end{array}$ & $\begin{array}{c}1.5 \\
0.8-2.5\end{array}$ & $\begin{array}{c}4.5 \\
2.8-5.6\end{array}$ & $\begin{array}{c}0.17 \\
0.07-0.26\end{array}$ & $\begin{array}{c}0.3 \\
0.1-0.6\end{array}$ & $\begin{array}{c}0.62 \\
0.28-0.95\end{array}$ & $\begin{array}{c}0.03 \\
0.02-0.05\end{array}$ & $\begin{array}{c}6 \\
4-10\end{array}$ & $\begin{array}{c}0.03 \\
0.01-0.09\end{array}$ & $\begin{array}{c}69 \\
8-120\end{array}$ & $\begin{array}{c}65 \\
10-154\end{array}$ \\
\hline
\end{tabular}



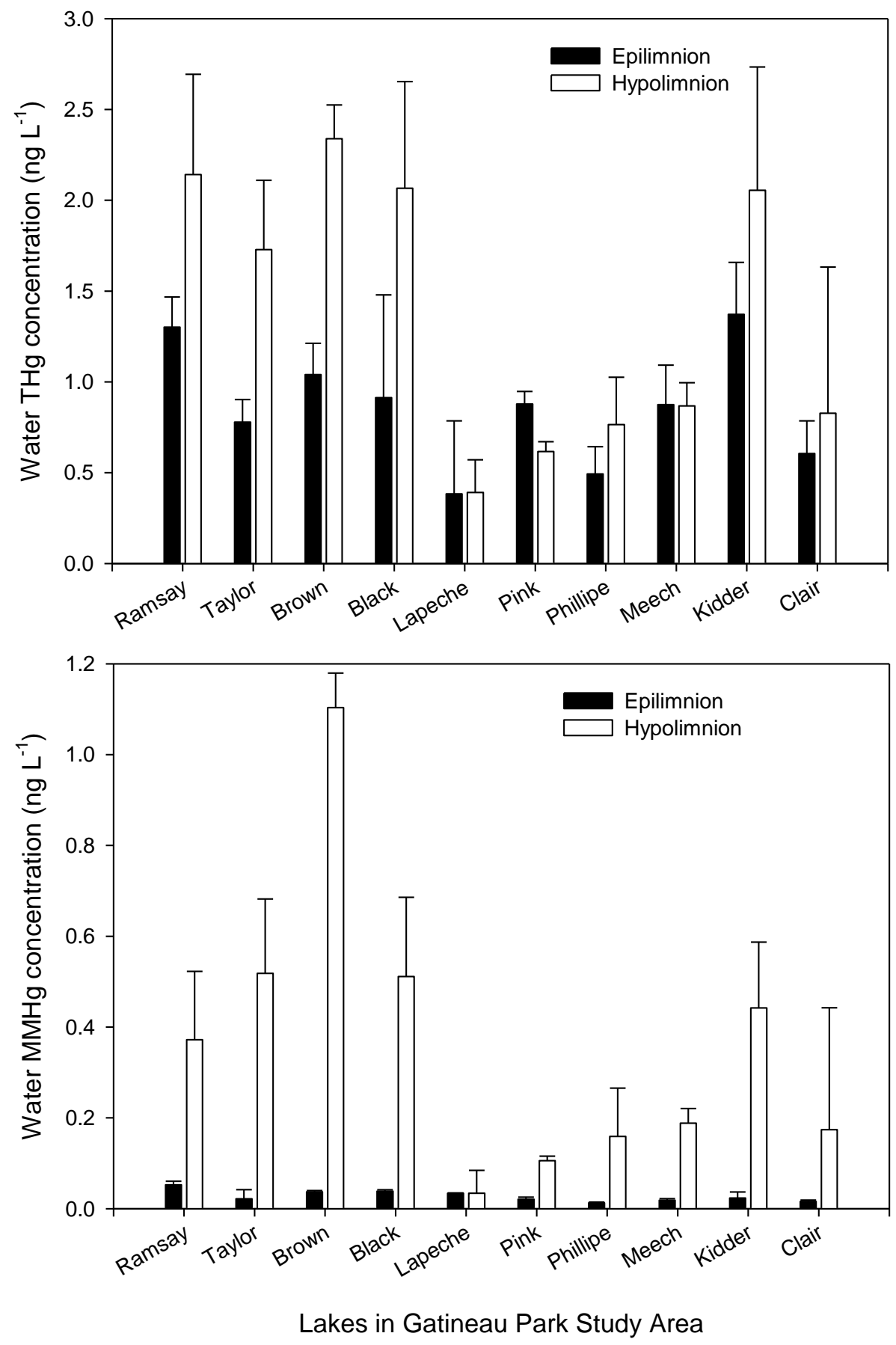

Figure S4. Comparison of surface water (epilimnion) and bottom water (hypolimnion) concentrations of $\mathrm{THg}$ (top panel) and $\mathrm{MMHg}$ (bottom panel) in stratified Gatineau Park lakes. Values are means ( \pm 1 standard error) of early summer and fall measurements in 2011 and 2012 (3-4 sampling dates). 
Table S4. Multiple regression models explaining MMHg concentrations of aquatic invertebrates in relation to surface water concentrations of $\mathrm{MMHg}, \mathrm{DOC}, \mathrm{Chl}$ and TN.

\begin{tabular}{|c|c|c|c|}
\hline $\begin{array}{l}\text { Response } \\
\text { Variable }\end{array}$ & Model Equation & $\begin{array}{c}\text { Model } \\
r_{a d j}^{2}\end{array}$ & $\begin{array}{l}\text { Model } \\
p\end{array}$ \\
\hline \multicolumn{4}{|c|}{ Log Chironomid MMHg $(n=35)$} \\
\hline & Model $1=1.408+13.113 \mathrm{MMHg}_{\text {water }}{ }^{\star \star *}-2.049 \log \mathrm{DOC}^{\star \star *}$ & 0.55 & $<0.001$ \\
\hline & $=0.459+10.995 \mathrm{MMHg}_{\text {water }}{ }^{\star \star *}-1.121 \log \mathrm{Chl}^{\star \star *}$ & 0.44 & $<0.001$ \\
\hline & $=-0.374+10.877 \mathrm{MMHg}_{\text {water }}{ }^{* *}-1.211 \log \mathrm{TN}^{*}$ & 0.22 & 0.007 \\
\hline \multicolumn{4}{|c|}{ Zooplankton MMHg $(n=34)$} \\
\hline & Model $4=45.676+723.733 \mathrm{MMHg}_{\text {water }}{ }^{\star *}-54.798 \log \mathrm{DOC}^{*}$ & 0.45 & $<0.001$ \\
\hline & $=-19.543+720.888 \mathrm{MMHg}_{\text {water }}{ }^{* *}-51.391 \log \mathrm{TN}^{*}$ & 0.41 & $<0.001$ \\
\hline & $=21.699+649.684 \mathrm{MMHg}_{\text {water }}{ }^{* *}-26.005 \mathrm{log} \mathrm{Chl}$ & 0.39 & $<0.001$ \\
\hline
\end{tabular}

$\log =\log$-transformed

Significance of individual variables: ${ }^{*} p<0.05,{ }^{* * *} p<0.001$ 


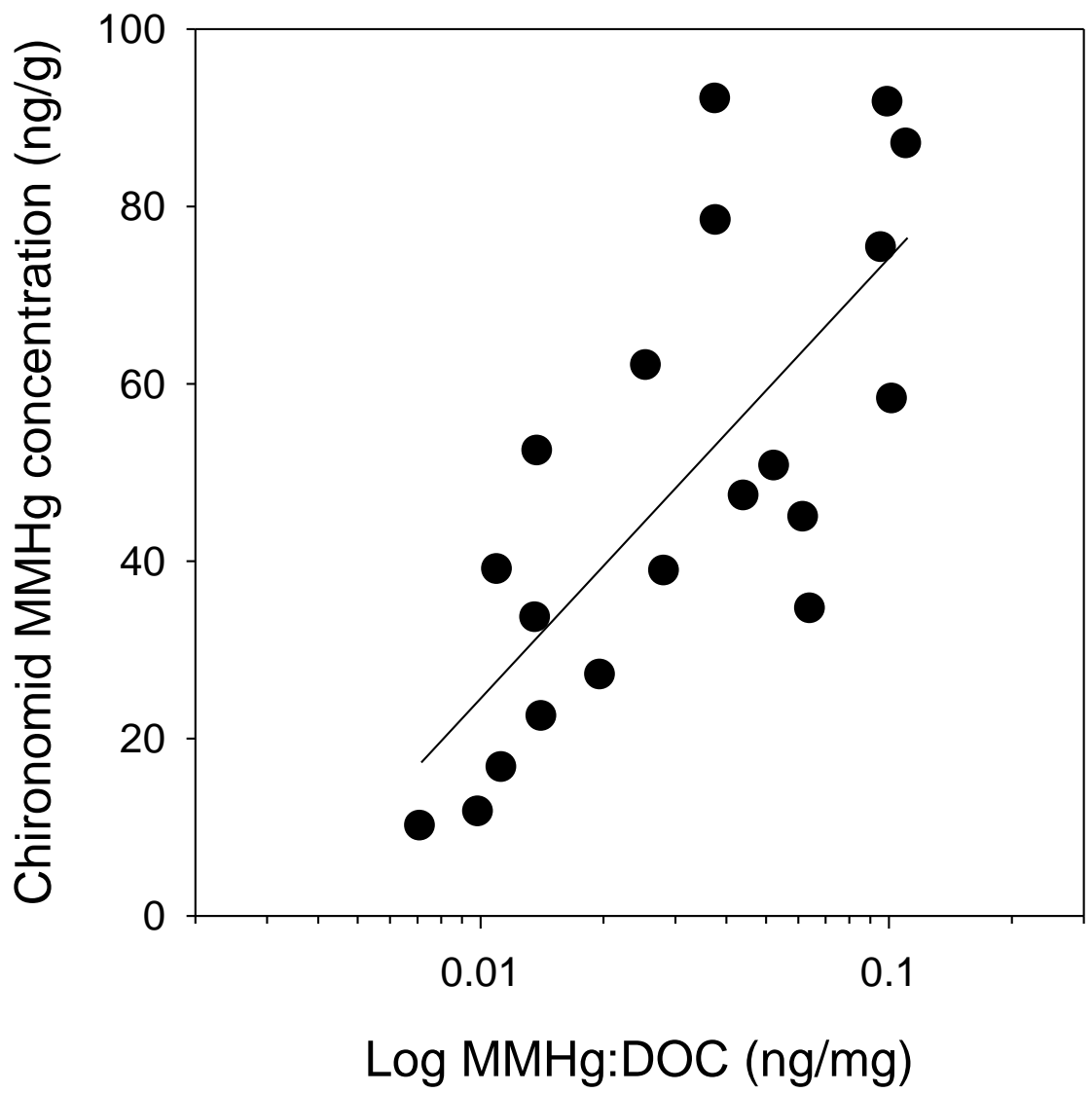

Figure S5. Relationship between $\mathrm{MMHg}$ concentration in chironomid larvae and the surface water MMHg:DOC ratio ( $r^{2} a d j=0.52, p<0.001, n=20$ lakes), following re-analysis of a previously published dataset for the Canadian high Arctic. Data points are lake-mean concentrations measured on 1 or 2 occasions in 2005 and/or 2006. An outlier lake with only 1 chironomid MMHg measurement was excluded from the regression. Ranges of surface water concentrations of DOC $(<0.6-7.4 \mathrm{mg} / \mathrm{L})$ and $\mathrm{MMHg}(<0.02-1.5 \mathrm{ng} / \mathrm{L})$ were observed among high Arctic study lakes because more productive polar oasis sites on Devon Island were sampled in addition to polar desert sites on Cornwallis and Somerset Islands. See Chetelat et al. ${ }^{4}$ for more detail on methods used to generate the dataset. 

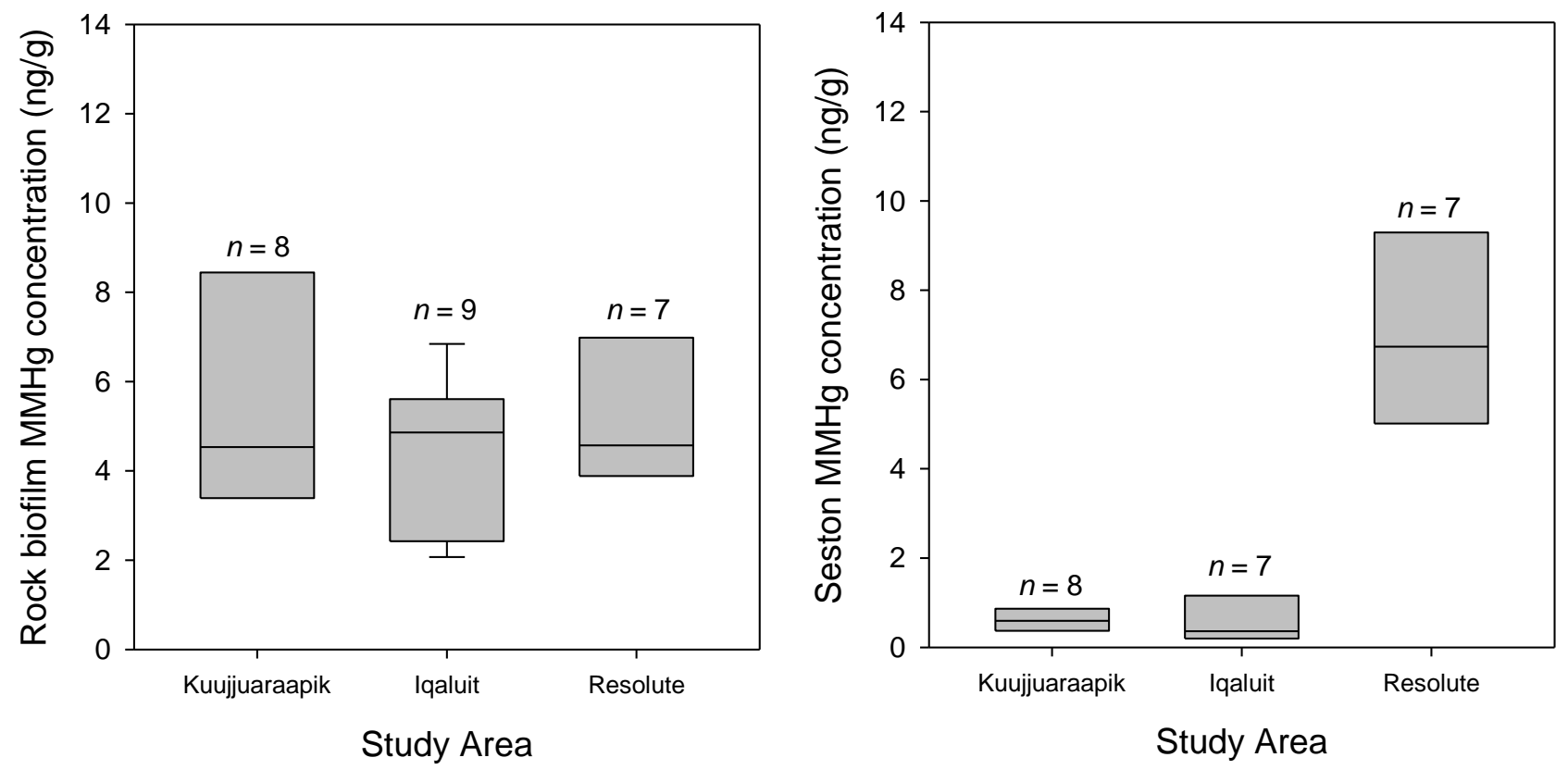

Figure S6. Boxplots of MMHg concentrations in rock biofilms and water seston from lakes in the three Arctic study areas. 


\section{REFERENCES}

1. Conrad, O.; Bechtel, B.; Bock, M.; Dietrich, H.; Fischer, E.; Gerlitz, L.; Wehberg, J.; Wichmann, V.; Böhner, J., System for Automated Geoscientific Analyses (SAGA) v. 2.1.4. Geoscientific Model Development 2015, 8, (7), 1991-2007.

2. Wetzel, R. G., Limnology: lake and river ecosystems. Gulf Professional Publishing: 2001.

3. Muir, D. C. G.; Wang, X.; Yang, F.; Nguyen, N.; Jackson, T. A.; Evans, M. S.; Douglas, M.; Kock, G.; Lamoureux, S.; Pienitz, R.; Smol, J. P.; Vincent, W. F.; Dastoor, A., Spatial trends and historical deposition of mercury in eastern and northern Canada inferred from lake sediment cores. Environ. Sci. Technol. 2009, 43, (13), 4802-4809.

4. Chételat, J.; Amyot, M.; Cloutier, L.; Poulain, A., Metamorphosis in chironomids, more than mercury supply, controls methylmercury transfer to fish in High Arctic lakes. Environ. Sci. Technol. 2008, 42, (24), 9110-9115. 